\title{
2. EXPLANATORY NOTES: ODP LEG 103 ${ }^{1}$
}

\author{
Shipboard Scientific Party ${ }^{2}$
}

Standard procedures for drilling operations and preliminary shipboard analysis of the material recovered have been regularly amended and upgraded since 1968 during Deep Sea Drilling Project (DSDP) and Ocean Drilling Program (ODP) investigations. This chapter presents information to help the reader understand the data-gathering methods on which our preliminary conclusions are based and help the investigator select samples for further analysis. This information primarily concerns shipboard operations and analyses described in the Leg 103 site reports (this volume). Methods used by various investigators for further shore-based analysis of Leg 103 data will be detailed in the individual scientific contributions published in Part B of this volume.

\section{AUTHORSHIP OF SITE REPORTS}

Authorship of the site reports is shared among the entire shipboard scientific party, although the two co-chief scientists and the staff scientist edited and rewrote part of the material

${ }^{1}$ Boillot, G., Winterer, E. L., Meyer, A. W., et al., Proc. Init. Repts. (Pt. A), $O D P, 103$.

${ }^{2}$ Gilbert Boillot (Co-Chief Scientist), Laboratoire de Géodynamique SousMarine, Université Pierre et Marie Curie, B. P. 48, 06230, Villefranche-sur-Mer, France; Edward L. Winterer (Co-Chief Scientist), Graduate Research Division A012-W, Scripps Institution of Oceanography, La Jolla, CA 92093; Audrey W. Meyer (ODP Staff Scientist), Ocean Drilling Program, Texas A\&M University, College Station, TX 77843-3469; Joseph Applegate, Department of Geology, Florida State University, Tallahassee, FL 32306; Miriam Baltuck, Department of Geology, Tulane University, New Orleans, LA 70118 (current address: NASA Headquarters, Code EEL, Washington, D.C. 20546); James A. Bergen, Department of Geology, Florida State University, Tallahassee, FL 32306; M. C. Comas, Departamento Estratigrafia y Paleontologia, Facultad de Ciencias, Universidad de Granada, 18001 Granada, Spain; Thomas A. Davies, Institute for Geophysics, University of Texas at Austin, 4920 North IH 35, Austin, TX 78751: Keith Dunham, Department of Atmospheric and Oceanic Sciences, University of Michigan, 2455 Hayward Avenue, Ann Arbor, MI 48109 (current address: P.O. Box 13, Pequat Lakes, MN 56478); Cynthia A. Evans, Department of Geology, Colgate University, Hamilton, NY 13346 (current address: Lamont-Doherty Geological Observatory, Palisades, NY 10964); Jacques Girardeau, Laboratoire de Materiaux Terrestres, I.P.G., 4 Place Jussieu, 75252 Paris Cedex 05, France; David Goldberg, Lamont-Doherty Geological Observatory, Palisades, NY 10964; Janet Haggerty, Department of Geology, University of Tulsa, $600 \mathrm{~S}$. College Avenue, Tulsa, OK 74104; Lubomir F. Jansa, Atlantic Geoscience Center, Bedford Institute of Oceanography, Dartmouth, Nova Scotia B2Y 4A2, Canada; Jeffrey A. Johnson, Department of Earth and Space Sciences, University of California, Los Angeles, CA 90024 (current address: 9449 Briar Forest Drive, No. 3544, Houston, TX 77063); Junzo Kasahara, Earthquake Research Institute, University of Tokyo, 1,1,1 Yayoi, Bunkyo, Tokyo 113, Japan (current address: Nippon Schlumberger K. K., 2-1 Fuchinobe, 2-chome, Sagamihara-shi, Kanagawa-ken, 229, Japan); Jean-Paul Loreau, Laboratoire de Géologie, Museum National D'Histoire Naturelle, 43 Rue Buffon, 75005 Paris, France; Emilio Luna, Hispanoil, Pez Volador No. 2, 28007 Madrid, Spain; Miche Moullade, Laboratoire de Géologie et Micropaleontologie Marines, Université de Nice, Parc Valrose, 06034 Nice Cedex, France; James Ogg, Geological Research Division A-012, Scripps Institution of Oceanography, La Jolla, CA 92093 (current address: Dept. Earth and Atmospheric Sciences, Purdue University, W. Lafayette IN 47907); Massimo Sarti, Istituto di Geologia, Universitá di Ferrara, Corso Ercole d'Este, 32, 44100 Ferrara, Italy; Jürgen Thurow, Institut und Museum für Geologie und Paleontologie, Universität Tuebingen, Sigwartstr. 10, D-7400 Tuebingen, Federal Republic of Germany; Mark A. Williamson, Atlantic Geoscience Centre, Geological Survey of Canada, Bedford Institute of Oceanography, Box 1006 , Dartmouth, Nova Scotia B2Y 4A2, Canada (current address: Shell Canada Ltd. P.O. Box 100, Stn. M, Calgary, Alberta T2P 2H5, Canada). prepared by other individuals. The site chapters are organized as follows (authorship in parentheses):

Principal Results (Boillot, Winterer)

Background and Objectives (Boillot)

Operations (Winterer)

Sediment Lithology (Comas, Davies, Jansa, Johnson, Loreau, Meyer, Sarti)

Basement Rocks (Evans, Girardeau)

Biostratigraphy (Applegate, Bergen, Moullade, Thurow, Williamson)

Paleomagnetics (Ogg)

Organic Geochemistry (Dunham)

Inorganic Geochemistry (Haggerty)

Physical Properties (Baltuck, Kasahara)

Age-vs.-Depth and Accumulation-Rate Curves (Winterer)

Logging Results (Luna, Goldberg)

Seismic Stratigraphy and Morphology of the Basement (Boillot, Winterer)

Summary and Conclusions (Boillot, Winterer)

Following the text are summary graphic lithologic and biostratigraphic logs, core descriptions ("barrel sheets"), and photographs of each core.

\section{SURVEY AND DRILLING DATA}

The survey data used for specific site selections are discussed in each site chapter. En route between sites, continuous observations were made of water depth and sub-bottom structure; the magnetometer was not working, so no magnetic field measurements were made. Short surveys using a precision echo-sounder and seismic profiler were made on board JOIDES Resolution before dropping the beacon.

All single-channel seismic-reflection data collected during Leg 103 are presented in the "Underway Geophysics" chapter (this volume). The standard seismic sources used during the cruise were two 80 -in. ${ }^{3}$ water guns. The seismic system was a super-micro Masscomp 561 computer. A 15-in.-wide Printronix high-resolution graphic printer (160 dots/in.) and a 22-in.-wide Versatec plotter ( 200 dots/in.) were available to plot the data. The raw data were recorded on tape using a SEG-Y format and a density of 1600 bytes/in. Real-time seismic data were also displayed in analog format on two EDO 550 dry-paper recorders, using only steamers, amplifier, and two band-pass filters.

Navigation data were collected on the bridge by a Magnavox MX702A.

Bathymetric data were obtained with both a $3.5-\mathrm{kHz}$ and a $12-\mathrm{kHz}$ echo-sounder, using a Raytheon recorder for the 3.5$\mathrm{kHz}$ echo-sounder and an EDO $248 \mathrm{C}$ recorder for the $12-\mathrm{kHz}$ echo-sounder. Depths were read on the basis of an assumed 1463 $\mathrm{m} / \mathrm{s}$ sound velocity. Water depth (in meters) at each site was corrected (1) according to the tables of Matthews (1939) and (2) for the depth of the hull transducer $(6 \mathrm{~m})$ below sea level. In addition, depths referred to the drilling-platform level are assumed to be $10.5 \mathrm{~m}$ above the water line. 


\section{DRILLING CHARACTERISTICS}

Because water circulation down the hole is open, drill cuttings were lost onto the seafloor and could not be recovered. The only information about characteristics of strata in uncored or unrecovered intervals, other than from seismic data or wireline-logging results, is from the drilling-penetration rates. Typically, the harder the layer being drilled, the slower and more difficult is penetration. Many other factors, however, not directly related to the hardness of the layers, also determine the rate of penetration. For example, the parameters of bit weight, pump pressure, and revolutions per minute, all noted on the drilling recorder, also influence the rate of penetration.

\section{DRILLING DEFORMATION}

When cores are split, some show signs of significant sediment disturbance. Examples of this disturbance include the downward-concave bending of originally horizontal layers, the haphazard mixing of lumps of different lithologies, and the nearfluid state of some sediments recovered from tens to hundreds of meters below the seafloor. Core deformation probably occurs during one of three different steps: cutting, retrieval (with accompanying changes in pressure and temperature), and core handling.

\section{SHIPBOARD SCIENTIFIC PROCEDURES}

\section{Numbering of Sites, Holes, Cores, and Samples}

ODP drill sites are numbered consecutively from the first site drilled by Glomar Challenger in 1968. A site number refers to one or more holes drilled while the ship is positioned over a single acoustic beacon. Several holes may be drilled at a single site by pulling the drill pipe above the seafloor (out of one hole), moving the ship some distance from the previous hole, and then drilling another hole.

For all ODP drill sites, a letter suffix distinguishes each hole drilled at the same site. For example: the first hole takes the site number with suffix $\mathrm{A}$, the second hole takes the site number with suffix B, and so forth. This procedure is different from that used by the DSDP (Sites 1-624) but prevents ambiguity between site and hole number designations.

All ODP core and sample identifiers indicate core type. The following abbreviations are used: $\mathrm{R}=$ rotary barrel; $\mathrm{H}=$ hydraulic piston core (HPC/APC), $\mathrm{P}=$ pressure core barrel; $\mathrm{X}=$ extended core barrel (XCB); $\mathrm{B}=$ drill-bit recovery; $\mathrm{C}=$ centerbit recovery; I = in-situ water sample; $\mathrm{S}=$ sidewall sample; $\mathrm{W}$ = wash core recovery, $\mathrm{N}=$ navidrill core (used only after Leg 103), and $\mathrm{M}=$ miscellaneous material. Only rotary and XCB cores were drilled on Leg 103.

The cored interval is measured in meters below the seafloor. The depth interval of an individual core is the depth below seafloor that the coring operation began to the depth that the coring operation ended. Each coring interval is as much as $9.7 \mathrm{~m}$ long, which is the maximum length of a core barrel. The coring interval may, however, be shorter. Cored intervals are not necessarily adjacent but may be separated by drilled intervals. In soft sediment, the drill string can be "washed ahead," keeping the core barrel in place but not recovering sediment, by pumping high-pressured water down the pipe to wash the sediment out of the way of the bit and up the annulus between the drill pipe and wall of the hole. If, however, thin, hard rock layers are present, it is possible to get "spotty" sampling of these resistant layers within the washed interval.

Cores taken from a hole are numbered serially from the top of the hole downward. Maximum full recovery from a single core is $9.7 \mathrm{~m}$ of sediment or rock in a plastic liner $(6.6 \mathrm{~cm}$ inner diameter), plus about a 0.2 -m-long sample (without a plastic liner) in a core catcher (CC). The core catcher, a device at the bottom of the core barrel, prevents the core from sliding out when the barrel is being retrieved from the hole. The sediment core is then cut into $1.5-\mathrm{m}$-long sections, which are numbered serially from the top of the core (Fig. 1); the routine for handling hard rocks is described in the section on basement rocks (this chapter). When full recovery is obtained, the sections are numbered from 1 through 7 , the last section being shorter than $1.5 \mathrm{~m}$. For sediments and sedimentary rocks, the core-catcher sample is placed below the last section and treated as a separate section. For igneous and metamorphic rocks, material recovered in the core catcher is included at the bottom of the last section.

When recovery is less than $100 \%$, whether or not the recovered material is contiguous, the recovered sediment is placed at the top of the cored interval, and then 1.5-m-long sections are numbered serially, starting with Section 1 at the top. There are as many sections as needed to accommodate the length of the core recovered (Fig. 1); for example, $3 \mathrm{~m}$ of core sample in a plastic liner will be divided into two 1.5 -m-long sections. Sections are cut starting at the top of the recovered sediment, and the last section may be shorter than the normal 1.5-m length. If, after the core has been split, fragments that are separated by a void appear to have been contiguous in situ, a note is made in the description of the section. All voids, whether real or artificial, are curatorially preserved.

Samples are designated by distances in centimeters from the top of each section to the top and bottom of the sample interval in that section. A full identification number for a sample consists of the following information: (1) leg, (2) site, (3) hole, (4) core number and type, (5) section, and (6) interval in centimeters. For example, the sample identification number "103-637A-3R$2,98-100 \mathrm{~cm}$ " indicates that a sample was taken between 98 and $100 \mathrm{~cm}$ from the top of Section 2 of rotary-drilled Core 3, from the first hole drilled at Site 637 during Leg 103. A sample taken from between 8 and $9 \mathrm{~cm}$ in the core catcher of this core is designated "103-637A-3R, CC (8-9 cm)."

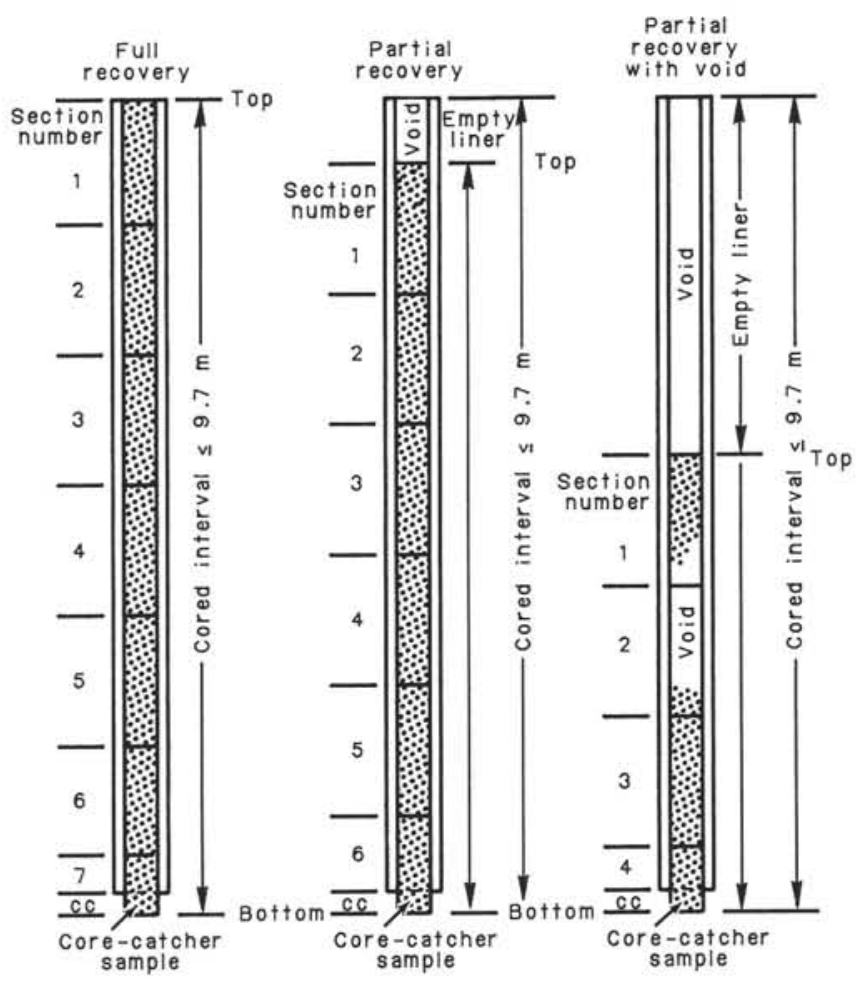

Figure 1. Examples of numbered core sections. 
With only two exceptions on Leg 103 (Cores 103-639A-1R and 103-639B-1R), the depth below the seafloor for a sample numbered, for example, "103-637A-3R-2, 98-100 cm," is the sum of the depth to the top of the cored interval for Core 3 $(11.8 \mathrm{~m})$ plus the $1.5 \mathrm{~m}$ included in Section 1 plus the $98 \mathrm{~cm}$ below the top of Section 2. The sample in question is therefore located at $14.28 \mathrm{~m}$ sub-bottom which, in principle, is the sample subseafloor depth (sample requests should refer to a specific interval within a core section rather than to sub-bottom depths in meters). Note that this assignment of the subseafloor depth is of course an arbitrary convention; in the case of less than $100 \%$ recovery, the sample could have come from any depth within the cored interval.

In Core 103-639A-1R, we cored $2.3 \mathrm{~m}$ but recovered $6.8 \mathrm{~m}$; in Core 103-639B-1R, we cored $7.2 \mathrm{~m}$ but recovered $9.7 \mathrm{~m}$ (see Site 639 chapter, this volume). These recoveries that are greater than the interval cored are attributed to soft sediment that expanded up into the barrel because the diameter of the hole drilled was greater than the diameter of the core liner. To assign subbottom depths to these cores, we proportionally assigned the amount of material recovered to the cored interval.

\section{Core Handling}

As soon as a core was retrieved on deck, a sample was taken from the core catcher and sent to the paleontological laboratory for an initial assessment of the age of the sample.

Next, the core was placed on the long horizontal rack on the catwalk, and gas samples were taken by piercing the core liner and withdrawing gas into a vacuum-tube sampler. Voids within the core were sought as sites for the gas sampling. Some of the gas samples were stored for shore-based study, but others were analyzed immediately as part of the shipboard safety and pollution-prevention program. Next, the core was marked into section lengths; each section was labeled, and the core was cut into sections. Interstitial-water (IW) and organic geochemistry (OG) whole-round samples were then taken as scheduled. Each section was sealed top and bottom with a plastic cap, blue to identify the top of a section and clear for the bottom. A yellow cap was placed on section ends from which a whole-round core sample had been removed. The caps were usually attached to the liner by coating the end of the liner and the inside rim of the end cap with acetone, though we elected to tape the end caps in place without acetone on samples taken at geochemically interesting parts of Site 641 .

The cores were then carried into the laboratory, and the complete identification was engraved on each section. The length of core in each section and the core-catcher sample was measured to the nearest centimeter; this information was logged into the shipboard core-log data-base program.

Next, the cores were allowed to warm to a stable temperature (approximately $4 \mathrm{hr}$ ) before splitting. During this time, the wholeround sections were run through the gamma ray attenuation porosity evaluation (GRAPE) device for estimating bulk density and porosity (see "Physical-Properties" section, this chapter; Boyce, 1976) and the three-axis, pass-through cryogenic rock magnetometer (see "Paleomagnetics" section, this chapter). After the temperature of the cores had reached equilibrium, thermal-conductivity measurements were made immediately before splitting (see "Physical-Properties" section, this chapter).

Cores of relatively soft material were split lengthwise into work and archive halves. The softer cores were split with a wire, and the harder ones with a band saw or diamond saw. In soft sediments, some smearing of material can occur; thus, to minimize contamination, scientists analyzing samples avoided using the near-surface part of the split core. Where the cored material was of uneven diameter or did not fill the entire diameter of the core liner, the diameter of the split core was measured with cali- pers at all significant points to provide the path-length data needed later to interpret the GRAPE data. These caliper data were recorded on the visual core-description forms.

The work half of the core was sampled for both shipboard and shore-based laboratory studies. Each extracted sample was logged in the sampling computer program by location and by the name of the investigator receiving the sample. Records of all removed samples are kept by the ODP Curator at Texas A\&M University. The extracted samples were sealed in plastic vials or bags and labeled with a computer-printed label. Samples were routinely taken for shipboard analysis of compressional sonic velocity by the Hamilton Frame method, of bulk density and water content by gravimetric analysis, and of percentage calcium carbonate by carbonate bomb. Many of these data are reported in the site chapters (this volume).

The archive half was described visually. Smear slides were made from samples taken from the archive half, and thin sections and acetate peels were made from the work half. The archive half of each core was then photographed with both blackand-white and color film.

Both halves were then put into labeled plastic tubes, sealed, and transferred to cold-storage space aboard the drilling vessel. Leg 103 cores were transferred from the ship via refrigerated vans to cold storage at the East Coast Repository, at LamontDoherty Geological Observatory, Palisades, New York.

\section{SEDIMENT CORE DESCRIPTION FORMS ("BARREL SHEETS")}

The Core Description Forms (Fig. 2), or "barrel sheets," summarize the data obtained during shipboard analysis of each core. The following discussion explains the ODP conventions used in compiling data for each part of the Core Description Form and the exceptions to these procedures adopted by Leg 103 scientists.

\section{Core Designation}

Cores are designated using leg, site, hole, and core number and type as previously discussed (see "Numbering of Sites, Holes, Cores, and Samples," this chapter). In addition, the cored inter$\mathrm{val}$ is specified in terms of meters below sea level (mbsl) and meters below seafloor (mbsf). On Leg 103, these depths were based on the drill-pipe measurement, as reported by the SEDCO coring technician and the ODP operations superintendent.

\section{Age Data}

Microfossil abundance, preservation, and zone assignment, as determined by the shipboard paleontologists, appear on the core description form under the heading "Biostratigraphic Zone/ Fossil Character." The geologic age determined from the paleontological and/or paleomagnetic results appears in the "TimeRock Unit" column.

On Leg 103, planktonic foraminifers and calcareous nannofossils provided most age determinations, although radiolarians, benthic foraminifers, and calpionellids were also used. Detailed information on the zonations and terms used to report abundance and preservation appears in the "Biostratigraphy" section (this chapter).

\section{Paleomagnetic, Physical Properties, and Chemical Data}

Columns are provided on the core-description form to record paleomagnetic results, location of physical-properties samples (density, $\rho_{\mathrm{b}}$; velocity, $\mathrm{V}_{\mathrm{p}}$; undrained shear strength, $\gamma$; and thermal conductivity, $\mathrm{T}_{\mathrm{c}}$ ), and chemical data (percentage $\mathrm{CaCO}_{3}$, determined by the carbonate bomb). Physical-property data are presented in a table in the lower right corner of the core-description forms. Additional information on shipboard procedures for collecting these types of data appears in the "Paleomagnetics," 


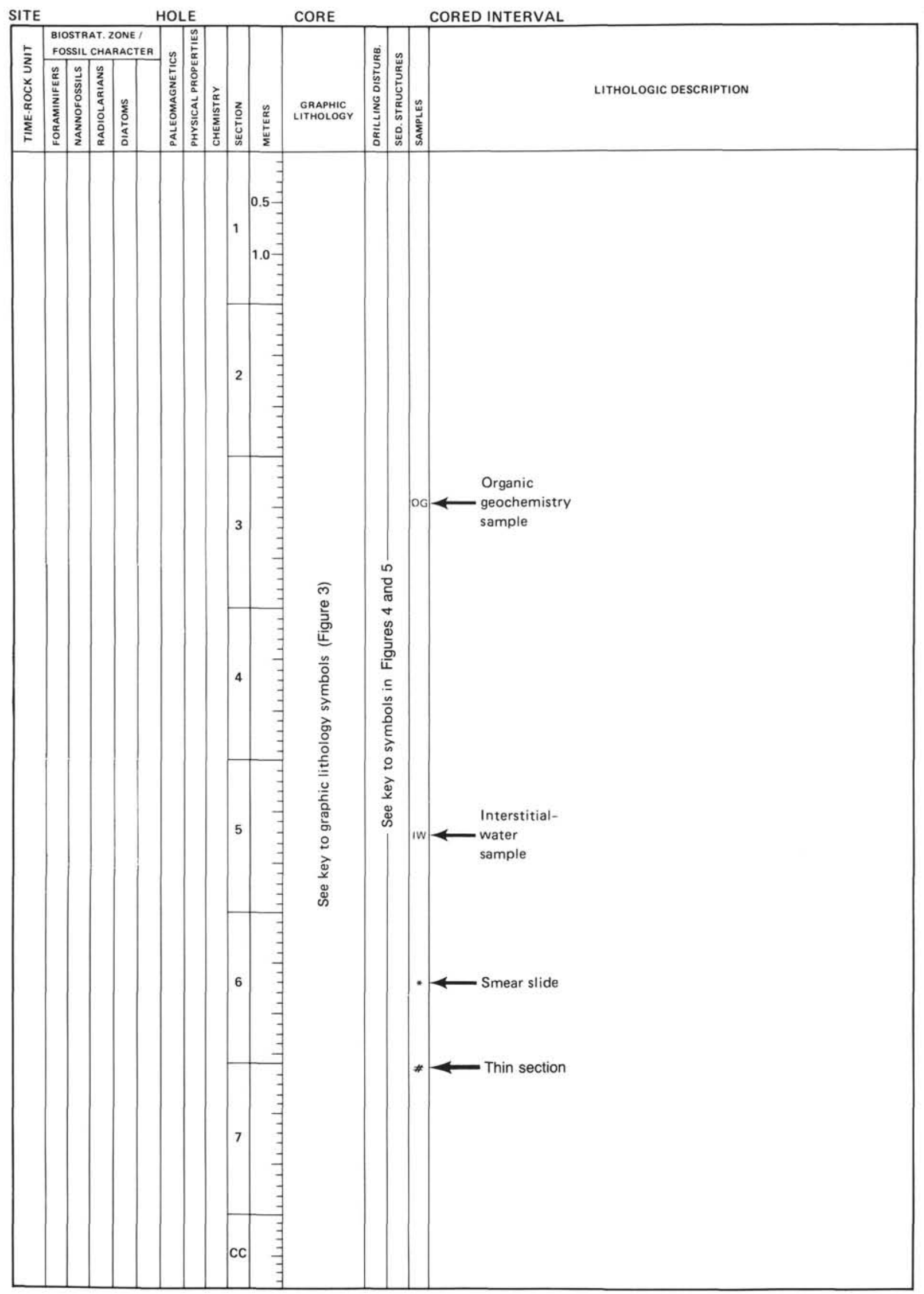

Figure 2. Core-description forms ("barrel sheets") used for sediments and sedimentary rocks. 
"Physical Properties," and "Inorganic Geochemistry" sections (this chapter).

\section{Graphic Lithology Column}

The lithology of the recovered material is represented on the core-description forms by a single symbol or by a group of two or more symbols (Fig. 3) in the column titled "graphic lithology." The symbols in a group correspond to end-members of sed- iment constituents, such as clay or nannofossil ooze. The symbol for the terrigenous constituent appears on the right side of the column, and the symbol for the biogenic constituent on the left side of the column. The abundance of any component approximately equals the percentage of the width of the graphic column that its symbol occupies. For example, the left $20 \%$ of the column may have a nannofossil-ooze symbol, whereas the right $80 \%$ may have a clay symbol, indicating sediment com-
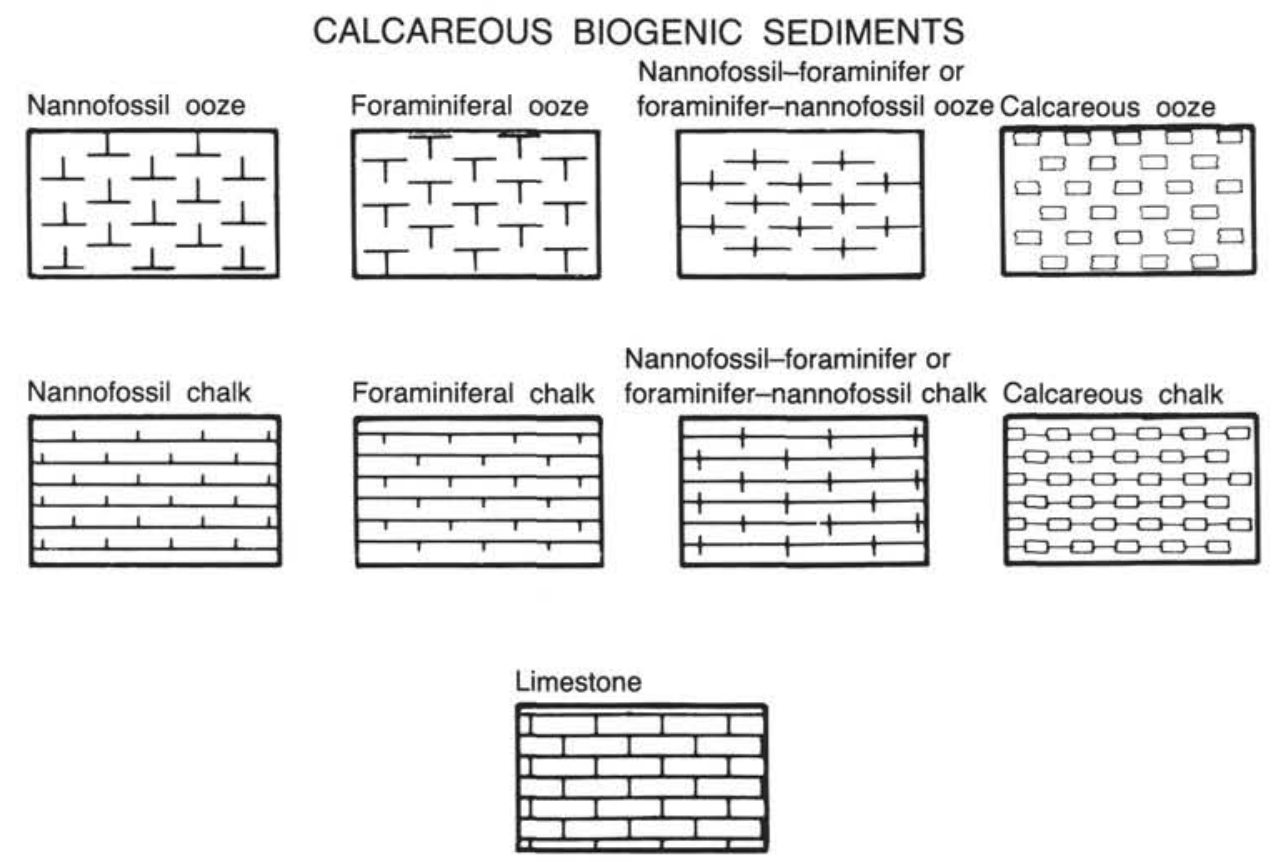

\section{TERRIGENOUS SEDIMENTS}

Sandy mud/
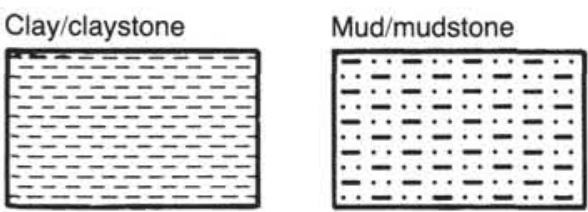

sandy mudstone

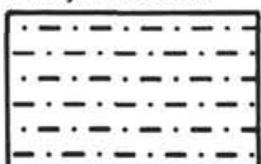

Silt/siltstone

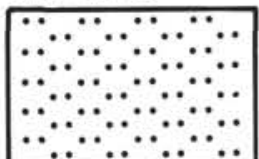

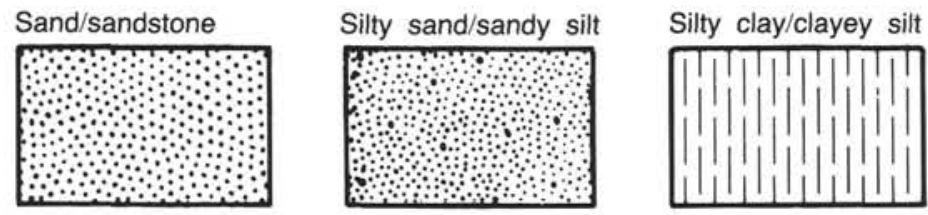

SPECIAL ROCK TYPES
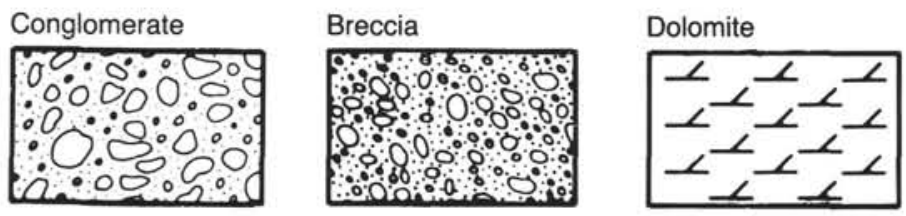

Concretions

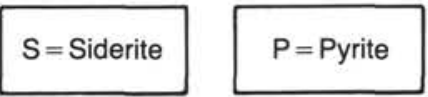

Drawn circle with symbol

Figure 3. Key to lithologic symbols used in "graphic lithology" column on core-description forms (see Fig. 2). 
posed of $20 \%$ nannofossils and $80 \%$ clay. Where different types of sediment are finely interbedded, symbols given in the "graphic lithology" column are schematic because the scale of the coredescription forms does not permit a more accurate display.

\section{Sediment Disturbance}

The coring technique, which uses a 25 -cm-diameter bit with a 6-cm-diameter core opening, can result in disturbance of the recovered core material. This is illustrated in the "drilling disturbance" column on the core-description form, which uses the symbols in Figure 4 to indicate the following disturbance categories for soft and firm sediments:

1. Slightly deformed: Bedding contacts are slightly bent.

2. Moderately deformed: Bedding contacts have undergone extreme bowing.

3. Very deformed: Bedding is completely disturbed and may show diapirlike or flow structures.

4. Soupy: Intervals are water saturated and have lost all aspects of original bedding and continuity.

The following categories describe the degree of fracturing in hard sedimentary rocks and igneous and metamorphic rocks:

1. Slightly fractured: Core pieces are in place and contain little drilling slurry or breccia.

2. Moderately fragmented: Core pieces are in place or partly displaced, but original orientation is preserved or recognizable. Drilling slurry may surround fragments.

3. Highly fragmented: Pieces are from the interval cored and probably in correct stratigraphic sequence (although they may not represent the entire section), but original orientation is totally lost.

4. Drilling breccia: Core pieces have completely lost their original orientation and stratigraphic position and may be completely mixed with drilling slurry.

The Leg 103 scientific party also defined and used a symbol, labeled "drilling contact" in Figure 4, to indicate lithologic contacts inferred to have been created by drilling techniques.

\section{Sedimentary Structures}

In sediment cores, natural structures and structures created by the coring process can be difficult to distinguish. Natural structures observed are indicated on the "sedimentary structure" column of the core-description forms. A key to the structural symbols used on Leg 103 is given in Figure 5.

\section{Samples}

The position of samples taken from each core for shipboard analysis is indicated in the "samples" column on the core-description form. An asterisk $\left(^{*}\right)$ indicates the location of smear slide samples; a pound sign (\#) indicates the location of thinsection samples. The symbols IW and OG designate whole-round interstitial-water and frozen organic geochemistry samples, respectively.

Although not indicated in the "samples" column, positions of samples for routine physical-properties analyses are indicated by a square in the "physical properties" column; locations of samples for carbonate-bomb analyses are indicated by a dot in the "chemistry" column. These samples were taken from the work half of the core and generally, although not always, correspond to smear slide locations in the archive half of the core. Carbonate-content data are given beside the sample dot; physical-properties data are listed below smear slide data in the lower right corner of the core-description form. Locations of samples for paleomagnetic analyses are indicated by a triangle in the "paleomag" column; polarity data are given beside the triangles.
Shipboard paleontologists usually base their age determinations on core-catcher samples, although additional samples from other parts of the core may be examined when required.

\section{Lithologic Description-Text}

The lithologic description that appears on each core-description form consists of two parts: (1) a heading that lists, in order of abundance, all the sediment types observed in the core (as determined using the sediment classification system; see "Sediment Classification" section, this chapter) and (2) a more detailed description of these sediments, including data on color, location in the core, significant features, and so forth.

\section{Smear Slide Summary}

A table summarizing data from smear slides and thin sections (where available) appears on each core-description form. The section and interval from which the sample was taken is noted, and whether the sample represents a dominant ("D") or a minor ("M") lithology in the core is indicated. The percentage of all identified components (totaling 100\%) is listed. As explained in the following text, these data are used to classify and name the recovered material.

\section{SEDIMENT CLASSIFICATION}

The classification system used during Leg 103 was a modification of that devised by the former Joint Oceanographic Institutions for Deep Earth Sampling (JOIDES) Panel on Sedimentary Petrology and Physical Properties and adopted for use by the JOIDES Planning Committee in March 1974.

Sediment and rock names were defined solely on the basis of composition and texture. These data were primarily determined on board ship by (1) microscopic observation of smear slides and thin sections, (2) visual observation of cores using a hand lens and binocular microscope, and (3) unaided visual observation. Calcium carbonate content was estimated in smear slides and by using the carbonate-bomb technique (Müller and Gastner, 1971). Other geologic features determined were color, sedimentary structures, and firmness.

\section{Color}

Colors of the recovered material were determined by comparison with Munsell soil-color charts immediately after the cores were split and while they were still wet. Information on core colors is given in the text of the "lithologic description" on the core-description forms (Fig. 2).

\section{Firmness}

Determination of induration is subjective. The criteria of Gealy et al. (1971) were used for calcareous deposits having more than $50 \%$ calcium carbonate; subjective estimates of behavior in core cutting or, more commonly, the "fingernail test" were used for transitional calcareous sediments of less than $50 \%$ calcium carbonate, biogenic siliceous sediment, pelagic clay, and terrigenous sediments.

We used three classes of firmness for calcareous sediments (Gealy et al., 1971):

1. Soft: Sediments that have little strength and are readily deformed under the fingernail or broad blade of the spatula are termed ooze.

2. Firm: Partly lithified ooze or friable limestone is called chalk. Chalks are readily deformed under the fingernail or the edge of a spatula blade.

3. Hard: The term Limestone is restricted to nonfriable cemented rock. 


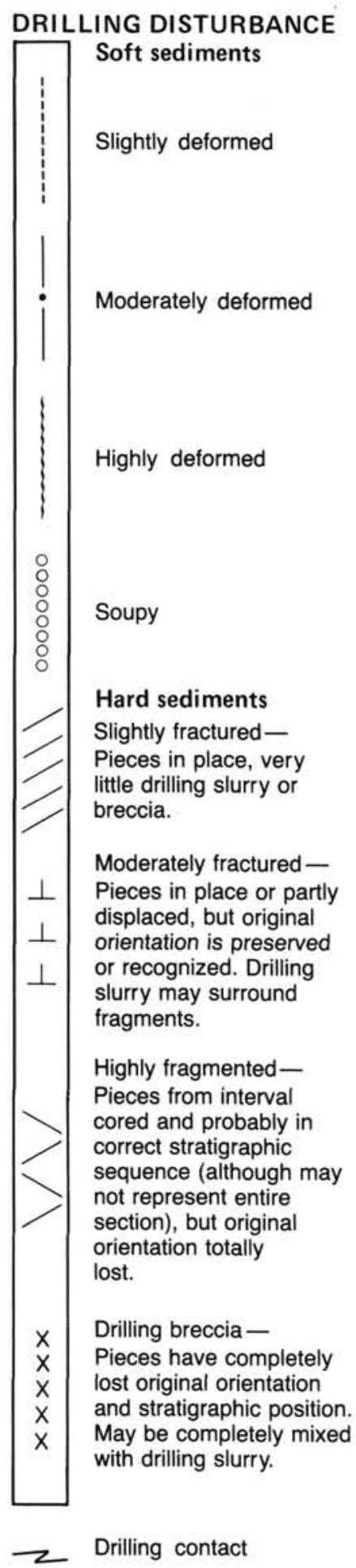

Figure 4. Drilling disturbance symbols used on Leg 103 core-description forms.

We used only two classes of firmness for transitional calcareous and noncalcareous sediments:

1. Soft: Sediment core can be split with a wire cutter or can be readily deformed under the fingernail. Soft terrigenous sediment, pelagic clay, and transitional calcareous biogenic sediments are termed sand, silt, clay, or mud.

2. Hard: Sediment core must be cut with a band saw or diamond saw or cannot be easily deformed under the fingernail.

\section{SEDIMENTARY STRUCTURES}

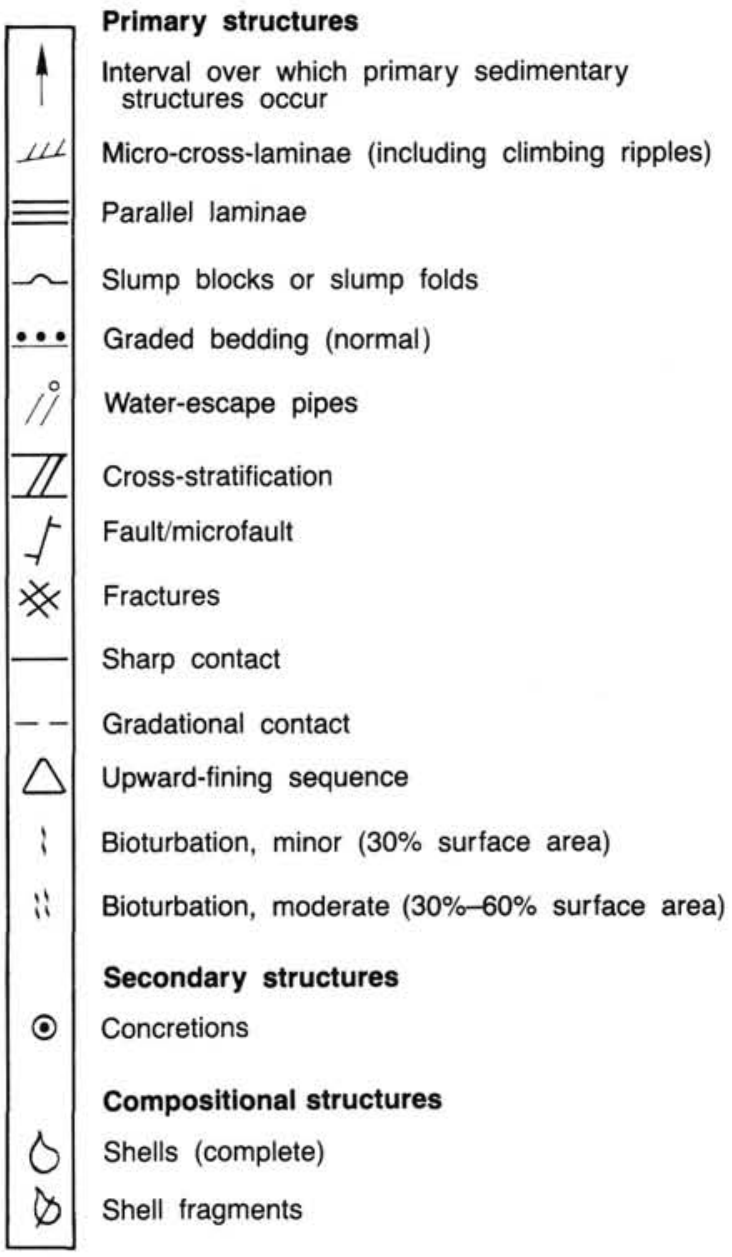

Figure 5. Sedimentary structure symbols for sediments and sedimentary rocks.

For these materials, the suffix -stone is added to the soft-sediment name (e.g., sandstone, siltstone, claystone, mudstone).

\section{Basic Sediment Types}

The sediment classification scheme used during Leg 103 was modified from the standard DSDP sediment classification scheme (e.g., Supko et al., 1978). The entire classification scheme is outlined in the following text for the sake of completeness, even though not all sediment categories are represented in Leg 103 cores.

\section{Pelagic Clay}

Pelagic clay is principally composed of authigenic pelagic material that accumulated at slow rates. On Leg 103 we recovered clay that most likely includes a pelagic component, which we termed "brown clay." We are, however, uncertain of the origin of this clay and prefer to classify it under the "Terrigenous Sediment" category (see following text).

\section{Siliceous Biogenic Sediments}

Siliceous biogenic sediments are distinguished from pelagic clay because they contain common $(>10 \%)$ siliceous microfossils. Siliceous biogenic sediments are differentiated from the calcareous biogenic sediments by a calcium carbonate content of less than $30 \%$. 
The two categories of siliceous biogenic sediments are (1) pelagic siliceous biogenic sediments that contain greater than $30 \%$ siliceous microfossils and less than $30 \%$ silt and clay; and (2) transitional siliceous biogenic sediments that contain between $10 \%$ and $70 \%$ siliceous microfossils and greater than $30 \%$ silt and clay. Soft pelagic siliceous biogenic sediments are termed "siliceous ooze" ("radiolarian ooze" or "diatom ooze," depending on the dominant fossil component). Hard pelagic siliceous biogenic sediments include radiolarite, diatomite, porcellanite, and chert. Transitional siliceous biogenic sediments having less than $50 \%$ siliceous microfossils are termed "siliceous mud" (or "diatomaceous mud," if diatoms are the dominant fossil component) or "siliceous mudstone." Transitional siliceous biogenic sediments having greater than $50 \%$ siliceous microfossils are termed "muddy diatom ooze" or "muddy diatomite." A carbonate content of between $10 \%$ and $30 \%$ in siliceous biogenic sediments carries an appropriate qualifier such as "calcareous," "nannofossil," and so forth.

\section{Calcareous Biogenic Sediments}

The Leg 103 shipboard party chose to distinguish calcareous biogenic sediment by a biogenic calcium carbonate content greater than $35 \%$, differing from the $30 \%$ boundary used in the standard DSDP/ODP classification scheme (Supko et al., 1978). The two classes are (1) pelagic calcareous biogenic sediments, which contain $65 \%-100 \%$ biogenic calcium carbonate $(<30 \%$ silt and clay), and (2) transitional calcareous biogenic sediments, which contain $35 \%-65 \%$ biogenic calcium carbonate $(>30 \%$ silt and clay). Lithologic names given these sediment classes are also dependent on the degree of sediment consolidation, as shown in Table 1. Sediments belonging to other classification categories but containing $10 \%-35 \%$ calcareous components are given the modifier "calcareous" (or "foraminiferal" or "nannofossil," as appropriate).

Calcareous sediments and limestones containing sand-sized carbonate particles were classified according to an expanded Dunham scheme (modified from Dunham, 1962), in a manner similar to that used on ODP Leg 101 (Table 2).

\section{Terrigenous Sediments}

Sediments and sedimentary rocks falling in the "Terrigenous Sediments" part of the classification scheme are subdivided into textural groups on the basis of the relative proportions of three grain-size constituents, i.e., clay, silt, and sand. Terrigenous sediments containing material larger than sand size are classed as conglomerate or breccia, clast-supported or matrix-supported, and are treated as "Special Rock Types" (Fig. 3). The size limits for these constituents are those defined by Wentworth (1922) (Fig. 6).

Seven major textural groups are defined in Figure 7. The groups are differentiated according to the abundance of clay $(>75 \%$, $75 \%-50 \%, 50 \%-10 \%,<10 \%)$ and the ratio of sand to silt $(>1$ or $<1)$. The terms clay, silty clay, sandy clay, clayey silt, clayey sand, silt, and sand are used for soft sediments. For hard sedi-

Table 1. Leg 103 classification of calcareous biogenic sediments and sedimentary rocks on the basis of carbonate content and degree of induration.

\begin{tabular}{clcc}
\hline $\begin{array}{c}\text { Carbonate } \\
\text { contents }\end{array}$ & Unconsolidated & Semilithified & \multicolumn{1}{c}{ Lithified } \\
\hline $0 \%-10 \%$ & Clay & \multicolumn{2}{c}{ Claystone } \\
$10 \%-35 \%$ & Calcareous clay & \multicolumn{2}{c}{ Calcareous claystone } \\
$35 \%-65 \%$ & Marl & \multicolumn{2}{c}{ Marlstone } \\
$65 \%-90 \%$ & Clayey ooze & Clayey chalk & Clayey limestone \\
$90 \%-100 \%$ & Ooze & Chalk & Limestone
\end{tabular}

ments and sedimentary rocks, the equivalent textural groups are claystone, silty claystone, sandy claystone, clayey siltstone, clayey sandstone, siltstone, and sandstone.

In the terrigenous sediment category, a variety of modifiers can be used (e.g., glauconitic, pyritic, feldspathic), typically describing the presence of minor constituents. Terrigenous sediments and sedimentary rocks containing 10\%-35\% calcium carbonate are qualified by the modifier "calcareous."

\section{Volcanogenic Sediments}

Pyroclastic rocks are described according to the textural and compositional scheme of Wentworth and Williams (1932). The textural groups are (1) volcanic breccia ( $>32 \mathrm{~mm}$ in size), (2) volcanic lapilli (4-32 $\mathrm{mm}$ in size), and (3) volcanic ash, tuff if indurated (less than $4 \mathrm{~mm}$ in size). Compositionally, these pyroclastic rocks are described as vitric (glass), crystal, or lithic.

Clastic sediments of volcanic provenance are described in the same fashion as terrigenous sediments, noting the dominant composition of the volcanic grains where possible. No volcanogenic sediments were recovered during ODP Leg 103.

\section{Special Sedimentary Rock Types}

The only "special" sedimentary rock types (not included in the classification scheme described previously) recovered during Leg 103 are dolomite and conglomerate.

\section{BASEMENT-ROCK HANDLING AND CORE-DESCRIPTION FORMS}

Igneous and metamorphic rocks were split, using a rock saw with a diamond blade, into archive and work halves. The archive halves were described and the work halves were sampled on board ship. Each piece of rock was numbered sequentially from the top of each core section, beginning with the number 1 . Pieces were labeled on the rounded, unsawed surface. Pieces that could be fitted together before splitting were given the same number but were consecutively lettered as $1 \mathrm{~A}, 1 \mathrm{~B}, 1 \mathrm{C}$, and so on. Spacers were placed between pieces having different numbers but not between those having different letters and the same number. In general, spacers are placed at interpreted drilling gaps (no recovery). The stratigraphic orientation is known for all pieces that are cylindrical in the liner and are of greater length than the diameter of the liner; on these pieces, arrows point to the top of the section. Care was taken to ensure that correct stratigraphic orientation was preserved through every step of the sawing and labeling process. All pieces suitable for sampling programs that require known orientations are indicated by upward-pointing arrows on the igneous and metamorphic core-description forms (Fig. 8).

These special core-description forms are used for igneous and metamorphic rocks because igneous rock representation on standard sediment core-description forms (i.e., Fig. 2) would be too compressed to provide adequate information for potential sampling. Graphic representations of each $1.5-\mathrm{m}$ core section are shown on these forms, along with summary hand-specimen and thin-section descriptions (Fig. 8). Textural and alteration symbols used on the core-description forms are given in Figure 9.

\section{IGNEOUS AND METAMORPHIC ROCK CLASSIFICATION}

Igneous and metamorphic rocks are classified mainly on the basis of mineralogy and texture determined by examination of hand specimens. Thin-section study allows for detailed assessment of features such as type and extent of alteration. Serpentinized peridotites and rhyolitic volcanic rocks were the only igneous rock types recovered on Leg 103. A few pieces of metamorphic rocks were also recovered. 
Table 2. Leg 103 classification of carbonate rocks, according to depositional texture. Amplification of original Dunham (1962) classification of limestones according to depositional textures of Embry and Klovan (1971, fig. 2), courtesy of Canadian Society of Petroleum Geologists. From Wilson (1975).

\begin{tabular}{|c|c|c|c|c|c|c|c|c|}
\hline \multicolumn{6}{|c|}{$\begin{array}{l}\text { Allochthonous limestones - } \\
\text { original components not organically } \\
\text { bound during deposition }\end{array}$} & \multicolumn{3}{|c|}{$\begin{array}{l}\text { Autochthonous limestones - } \\
\text { original components organi- } \\
\text { cally bound during deposition }\end{array}$} \\
\hline \multicolumn{4}{|c|}{ Less than $10 \%>2 \mathrm{~mm}$ components } & \multicolumn{2}{|c|}{$\begin{array}{l}\text { Greater than } \\
10 \%>2 \mathrm{~mm} \\
\text { components }\end{array}$} & \multirow{4}{*}{$\begin{array}{c}\text { By } \\
\text { organ- } \\
\text { isms } \\
\text { that } \\
\text { act } \\
\text { as } \\
\text { baffles }\end{array}$} & \multirow{4}{*}{$\begin{array}{l}\text { By } \\
\text { organ- } \\
\text { isms } \\
\text { that } \\
\text { encrust } \\
\text { and } \\
\text { bind }\end{array}$} & \multirow{4}{*}{$\begin{array}{c}\text { By } \\
\text { organ- } \\
\text { isms } \\
\text { that } \\
\text { build } \\
\text { a rigid } \\
\text { frame- } \\
\text { work }\end{array}$} \\
\hline Cor & $\begin{array}{l}\text { tains lime } \\
<.03 \mathrm{~mm}\end{array}$ & & $\begin{array}{l}\text { No } \\
\text { lime } \\
\text { mud }\end{array}$ & \multirow{3}{*}{$\begin{array}{l}\text { Matrix } \\
\text { sup- } \\
\text { ported }\end{array}$} & \multirow{3}{*}{$\begin{array}{l}>2 \mathrm{~mm} \\
\text { com- } \\
\text { ponent } \\
\text { sup- } \\
\text { ported }\end{array}$} & & & \\
\hline \multicolumn{2}{|c|}{ Mud supported } & \multirow{2}{*}{\multicolumn{2}{|c|}{$\begin{array}{c}\text { Grain } \\
\text { supported }\end{array}$}} & & & & & \\
\hline $\begin{array}{l}\text { Less than } \\
10 \% \\
\text { grains } \\
(>.03 \mathrm{~mm} \\
<2 \mathrm{~mm})\end{array}$ & $\begin{array}{l}\text { Greater } \\
\text { than } \\
10 \% \\
\text { grains }\end{array}$ & & & & & & & \\
\hline $\begin{array}{l}\text { Mud- } \\
\text { stone }\end{array}$ & $\begin{array}{l}\text { Wacke- } \\
\text { stone }\end{array}$ & $\begin{array}{l}\text { Pack- } \\
\text { stone }\end{array}$ & $\begin{array}{l}\text { Grain- } \\
\text { stone }\end{array}$ & $\begin{array}{l}\text { Float- } \\
\text { stone }\end{array}$ & $\begin{array}{l}\text { Rud- } \\
\text { stone }\end{array}$ & $\begin{array}{l}\text { Baffle- } \\
\text { stone }\end{array}$ & $\begin{array}{l}\text { Bind- } \\
\text { stone }\end{array}$ & $\begin{array}{l}\text { Frame- } \\
\text { stone }\end{array}$ \\
\hline
\end{tabular}

\section{Peridotite}

Peridotite samples were recovered at Site 637. The primary mineralogy of these samples is relatively uniform. Thus, distinctions were based upon grain size, abundance and deformation of pyroxene porphyroclasts, foliation, and degree of alteration.

All the peridotites were classified as altered, porphyroclastic harzburgites and labeled as either pyroxene-rich $(>10 \%$ pyroxene) or pyroxene-poor ( $<10 \%$ pyroxene). On the basis of the size of the pyroxene porphyroclasts, the samples were termed either coarse- or fine-crystalline peridotite. Peridotite samples having crystals less than about 3-4 $\mathrm{mm}$ in diameter were described as "fine crystalline."

All rocks display a primary foliation, defined by parallel alignment of both orthopyroxene and chrome-spinel crystals, and a secondary foliation. Other prominent features include calcite and serpentine veining and brecciation. These observations are noted on the core-description forms.

\section{Rhyolite}

Only $45 \mathrm{~cm}$ of rhyolitic rocks were recovered from two holes (Holes 639E and 639F). They are porphyritic rhyolites or rhyodacites. Although highly altered, phenocryst assemblages could be identified, and the classification of these rocks was based on this information.

\section{Metamorphic Rocks}

A few pieces of metasedimentary rocks and metamorphic quartzite breccia were recovered from Holes 639E and 639F. Classification of these samples was based on hand-specimen and thinsection identification.

\section{BIOSTRATIGRAPHY}

\section{Time Scale}

Time scales, which were recently published by Harland et al. (1982), Palmer et al. (1983), and Berggren et al. (1983, in press), were slightly modified and used on Leg 103 for correlation of Neogene-Quaternary zonal schemes (Fig. 10). For the Mesozoic, the time scales of Harland et al. (1982) and Palmer et al. (1983) were used (Fig. 11).

\section{Foraminifer Zonation}

The planktonic foraminiferal zonal schemes used for Neogene-Quaternary sediments recovered during Leg 103 follow those of Blow (1969) (N-sequence, as amended by Berggren, 1983), Berggren (1977) (PL zonation), and Berggren et al. (1983) (M zonation) (Fig. 10). Additional information was also derived from Kennett and Srinivasan (1983). The uppermost Jurassic through Early/middle Cretaceous planktonic and benthic foraminiferal zonation follows that of Moullade (1966, 1974, 1979, 1983, in press) and Magniez-Jannin et al. (1984). This zonation is directly calibrated with ammonites in Tethyan field sections (Fig. 11).

\section{Foraminifer Abundance and Preservation}

The abundance of foraminifers contained in sediment samples studied is defined as follows:

$A=$ abundant (about $2 \mathrm{~cm}^{3}$ of dry foraminifer residue from a $10-\mathrm{cm}^{3}$ sample)

$\mathrm{C}=$ common (about $1 \mathrm{~cm}^{3}$ )

$\mathrm{F}=$ few (about $0.5 \mathrm{~cm}^{3}$ )

$\mathrm{R}=\operatorname{rare}\left(0.5 \mathrm{~cm}^{3}\right.$ or less $)$

The abundance of particular species in the assemblages in a residue is defined as follows:

$\mathrm{A}=$ more than $30 \%$ of the population

$\mathrm{C}=10 \%$ to $30 \%$

$\mathrm{F}=3 \%$ to $10 \%$

$\mathrm{R}=$ less than $3 \%$

Percentages were estimated by visual examination.

The degree of preservation is influenced by effects of diagenesis, epigenesis, abrasion, encrustation, and/or (most frequently in deep-sea sediments) dissolution. Symbols for the degree of foraminifer preservation are defined as follows:

$\mathrm{G}=$ good (dissolution effects rare and obscure)

$\mathrm{M}=$ moderate (dissolution common but minor)

$\mathrm{P}=$ poor (specimen identification difficult or impossible)

\section{Nannofossil Zonation}

Zonation schemes used for the Cenozoic include those of Gartner (1977) for the Pleistocene and Okada and Bukry (1980) for pre-Pleistocene age assignments; the latter is based on stud- 


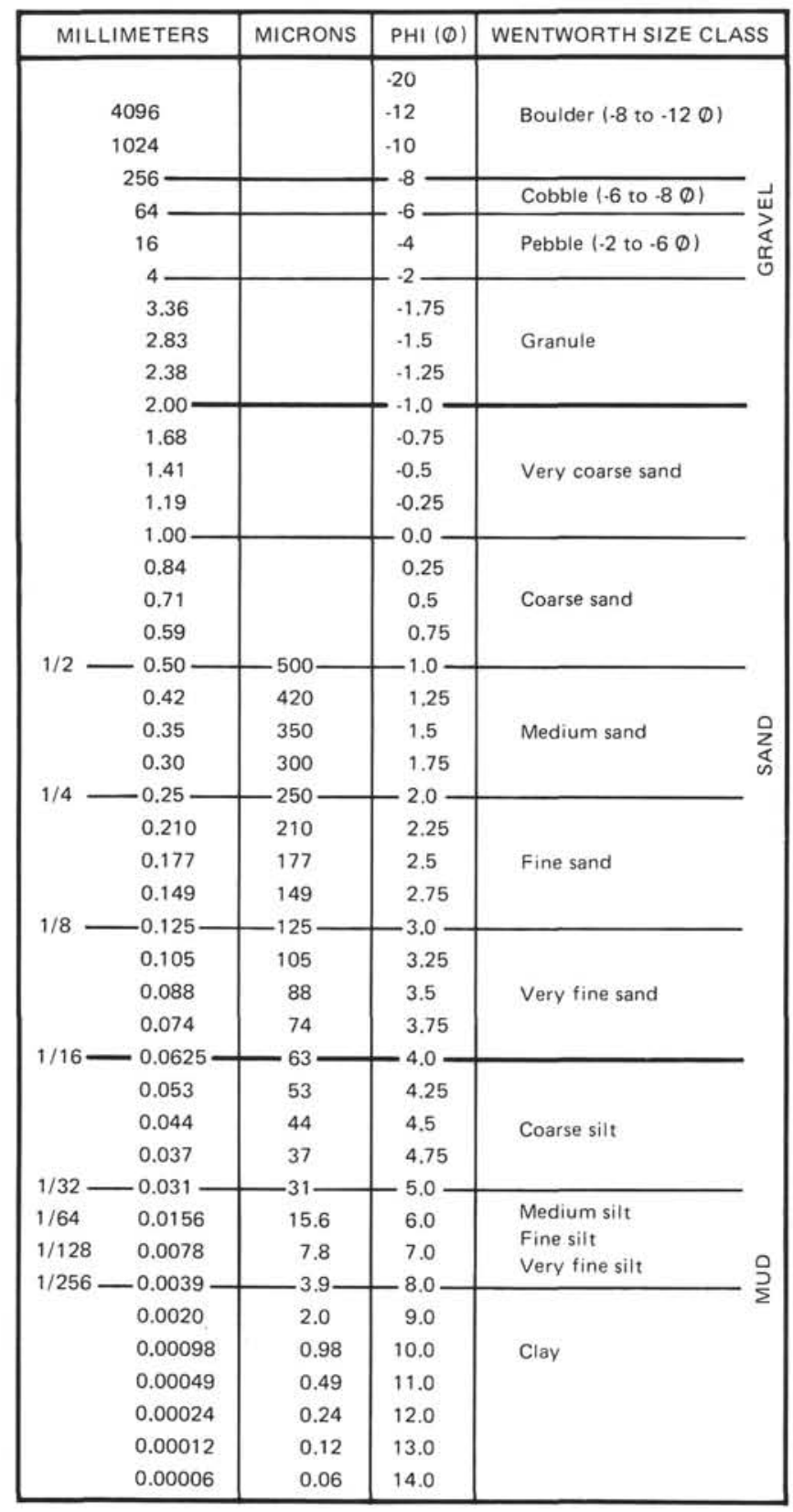

Figure 6. Grain-size categories used for classification of terrigenous sediments (from Wentworth, 1922).

ies by Bukry $(1973,1975)$ (Fig. 10). The zonal scheme of Gartner gives a higher resolution than that of Okada and Bukry.

Various zonal schemes were used for the Mesozoic (Fig. 11). For the middle Cretaceous, that of Manivit et al. (1977) was used. The zonal scheme of the Early Cretaceous is that of Sissingh (1977), which is based extensively on Thierstein $(1971,1973)$. Other studies providing information about the Early Cretaceous zonation include Perch-Nielsen (1979) and Roth (1983). The zonal scheme for the Late Jurassic is that of Roth et al. (1983), originally proposed for Site 534 on DSDP Leg 76.

\section{Nannofossil Abundance and Preservation}

Smear slides were prepared from raw sediment for examination of calcareous nannofossils. The abundance of nannofossils was estimated as follows:

$\mathrm{A}=$ abundant (1 to 10 species per field of view)

$\mathrm{C}=$ common ( 1 specimen per 2 to 10 fields of view)

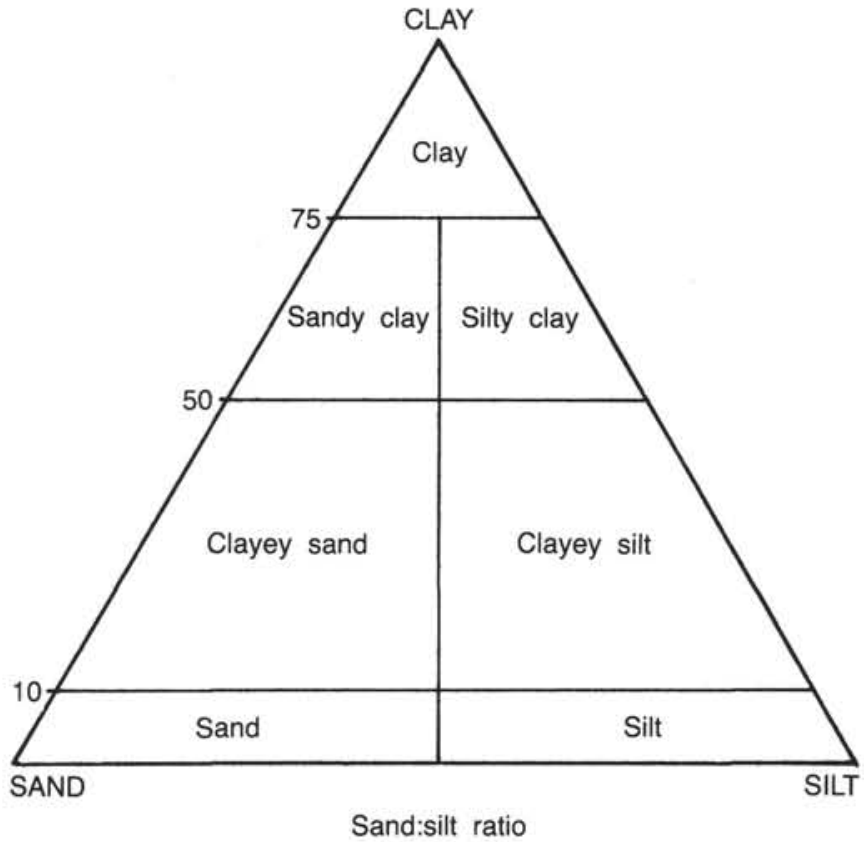

Figure 7. Classification scheme used for terrigenous sediments and sedimentary rocks on Leg 103.

$\mathrm{F}=$ few (1 specimen per 11 to 100 fields of view)

$\mathrm{R}=$ rare (1 specimen per 101 to 1000 fields of view)

This system was proposed by Hay (1970), using a magnification of $1000 \times$; a magnification of $1560 \times$ was used in this study.

The preservation state of nannofossils was designated as follows:

$\mathrm{G}=$ little or no evidence of overgrowth and/or etching of specimen

M = some degree of overgrowth and/or etching, but identification process generally not impaired

$\mathrm{P}=$ substantial overgrowth and/or etching; specimen identification difficult but possible

\section{Radiolarian Zonation}

The Early Cretaceous radiolarian zonation largely follows that described by Schaaf $(1981,1984)$ and the zonal scheme proposed by Baumgartner (1984) for Middle Jurassic to earliest Cretaceous (Fig. 11).

\section{Radiolarian Abundance and Preservation}

Radiolarian abundance was determined for the noncalcareous fraction (excluding mica and organic material) of the sediment sample. Therefore, radiolarian abundance is more an expression of sediment dilution by terrestrial input than of the total amount of radiolarians.

$A=$ more than 500 specimens in the noncalcareous fraction

$\mathrm{C}=100$ to 500 specimens in the noncalcareous fraction

$\mathrm{F}=10$ to 100 specimens in the noncalcareous fraction

$\mathrm{R}=$ at least three specimens in the noncalcareous fraction

Numbers of specimens were estimated by visual examination.

Effects of dissolution, recrystallization of the residues, and damage during possible transport of the radiolarians determine the degree of preservation (see Fig. 4 in Site 638 chapter, this volume).

$\mathrm{G}$ = replaced by pyrite but shape perfectly preserved, or dissolution effects rare and obscure on silica-preserved forms

M = Minor pyrite overgrowth, or dissolution of specimens common, but taxa-diagnostic test sculptures mainly preserved; diversity generally reduced 


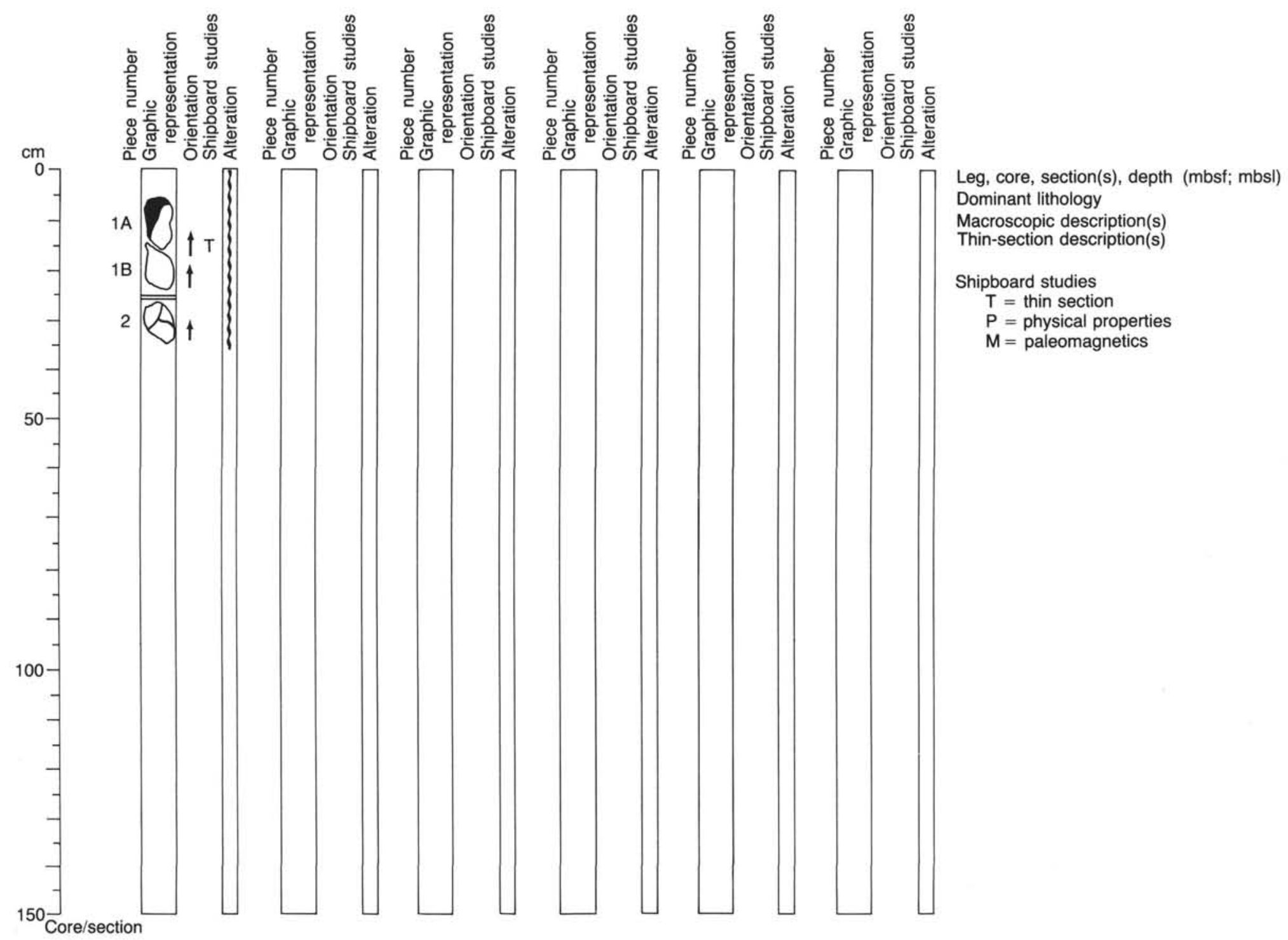

Figure 8. Core-description forms used for igneous and metamorphic rocks. 


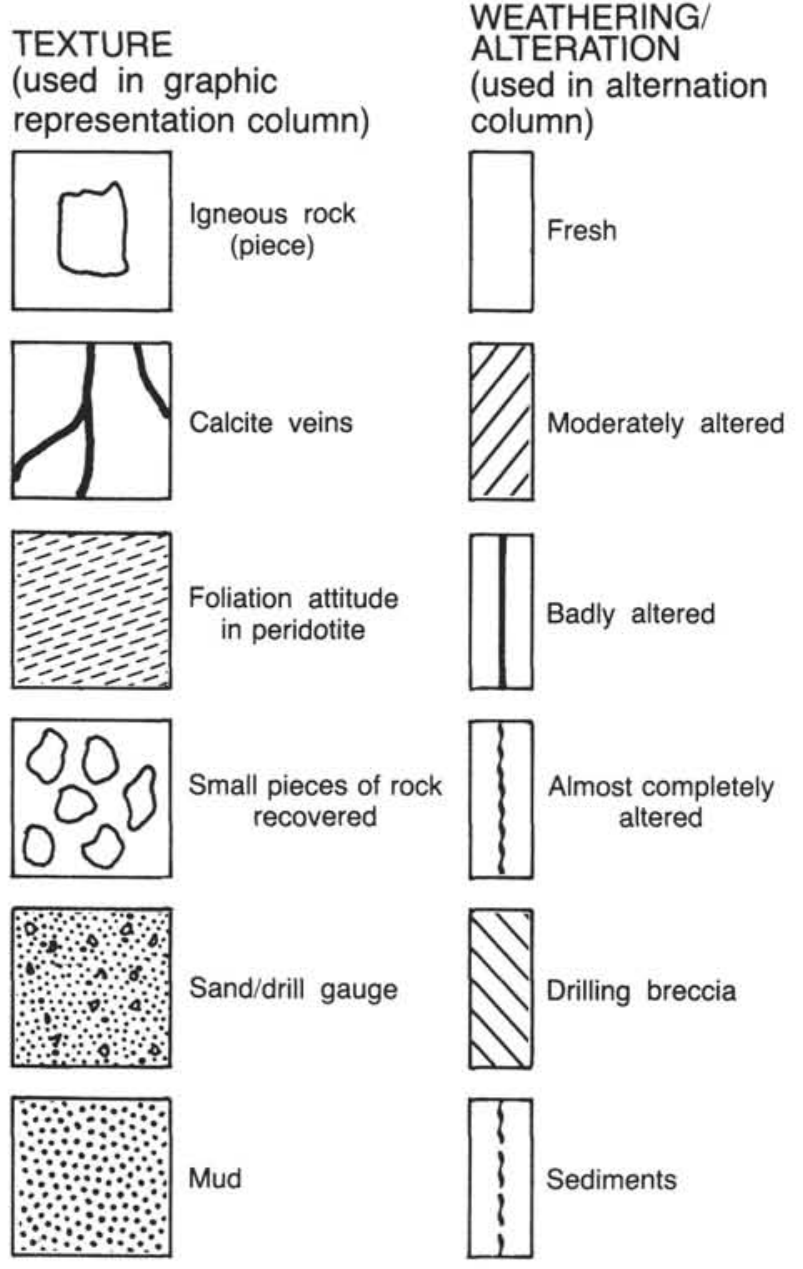

Figure 9. Textural and weathering/alteration symbols used on igneous and metamorphic rock core-description forms.

$\mathrm{P}=$ extensive overgrowth with pyrite crystals or only pyrite molds left, or strong dissolution of test patterns; encrustation or perforation and replacement by zeolites common; low diversity; thick-walled primitive forms dominate.

\section{Calpionellid Zonation}

The calpionellid zonal scheme applied to studies on Leg 103 is from Remane (1983) (Fig. 11). Additional information (e.g., calibration of the lower Valanginian calpionellids with ammonites and other microfossil groups) is derived from Busnardo et al. (1979).

\section{Calpionellid-Preparation Techniques}

Calpionellids were studied in thin sections of semilithified and lithified rock samples. Calpionellids were also recovered from soft sediments, and isolated specimens were then studied from coarse-fraction residues, using two techniques: (1) isolated specimens from residues examined with a scanning electron microscope and (2) strewn slides examined under a light microscope. The preparation of strewn slides follows the standard technique used for radiolarians except that no acid was used. Residues coarser than $45 \mu \mathrm{m}$ were suspended in water, then pipetted onto a slide, dried, and mounted in Canada balsam.
Abundance and preservation of calpionellids were estimated by visual examination.

\section{PALEOMAGNETICS}

Leg 103 was the first ODP cruise to have an on-board threeaxis cryogenic magnetometer (built by $2 \mathrm{G}$ Enterprises) capable of measuring both whole-round sections of cores and discrete samples. A three-axis alternating demagnetization (AF) unit and a magnetic-susceptibility meter are mounted on the cryogenic unit. Collection of all these data, including multiple-step AF demagnetization, is under direct control of a DEC PRO-350 minicomputer.

The magnetometer has great potential for obtaining detailed magnetostratigraphy from cores. It can process a 9-m-long core using $5-\mathrm{cm}$ spacing between measurements and three demagnetization steps, providing the final plot of declination and inclination within $2 \mathrm{hr}$. Determination of the magnetostratigraphy and intensity variations, therefore, would seem obtainable before the core had been split for visual observation and sampling. In practice, however, several obstacles severely limited the use of this cryogenic magnetometer for routine whole-round analysis of Leg 103 cores. The main problems were (1) rust-flake contamination from the old drill pipe used on the cruise and (2) distortion of the paleomagnetism by clastic-rich slurries formed during the rotary-drilling process. These effects dominated the magnetization of the whole-round sections. A special, coated drill pipe will be used to eliminate the severe rust-flake contamination on future cruises, but for Leg 103, the whole-round measurements had little value.

Discrete samples were obtained from every section containing undisturbed sediments, sedimentary rocks, or basement rocks. In very soft material, oriented samples were taken by pressing plastic boxes (6- $\mathrm{cm}^{3}$ internal volume) into the sediment, keeping one set of the sides parallel to the axis of the core. In some semi-indurated sediments, an oriented cube was cut out of the section, using an aluminum knife. This cube was then wrapped in aluminum foil for thermal demagnetization. The preferred sampling technique was to drill oriented minicores $(2.4-\mathrm{cm}$ diameter, 2.0-2.5-cm length) in the semi-indurated to lithified sediments and basement rocks. These were inscribed with an arrow parallel to the axis of the core. In sediments having a nonzero dip, the direction of dip relative to the axis of the minicore was recorded to provide a relative coordinate system for declination control on the paleomagnetic samples. Sampling density averaged about two minicores per recovered section.

Few of the discrete samples were measured on board ship for two reasons. First, most of the samples had extremely weak magnetizations (less than $1 \times 10^{-6} \mathrm{emu} / \mathrm{cm}^{3}\left[=1 \times 10^{-3} \mathrm{~A} / \mathrm{m}\right]$ ). In quiet seas, the noise level of the cryogenic magnetometer was sufficiently low to measure such samples (total noise intensity $=1 \times 10^{-7} \mathrm{emu}=1 \times 10^{-10} \mathrm{Am}^{3}$ ), but rolling of the ship in moderate seas introduced cyclic noise exceeding $2 \times 10^{-6} \mathrm{emu}$ $\left(=1 \times 10^{-9} \mathrm{Am}^{3}\right)$, which was too high a background level for accurately measuring the average $10-\mathrm{cm}^{3}$ sample. Second, thermal demagnetization equipment was not available on board ship. Based on previous studies of lithified Mesozoic sediments drilled at DSDP sites in the Atlantic, thermal demagnetization is necessary for removing normal-polarity overprints and obtaining the primary magnetostratigraphy (Steiner, 1977; Ogg, 1981; Ogg, in press). For these reasons, nearly all samples were instead analyzed on shore after the cruise.

In the site chapters (this volume), centimeter/gram/second (CGS) units are used rather than SI units because these are the metric units currently used by the shipboard laboratory equipment and computer programs and because CGS units are much 


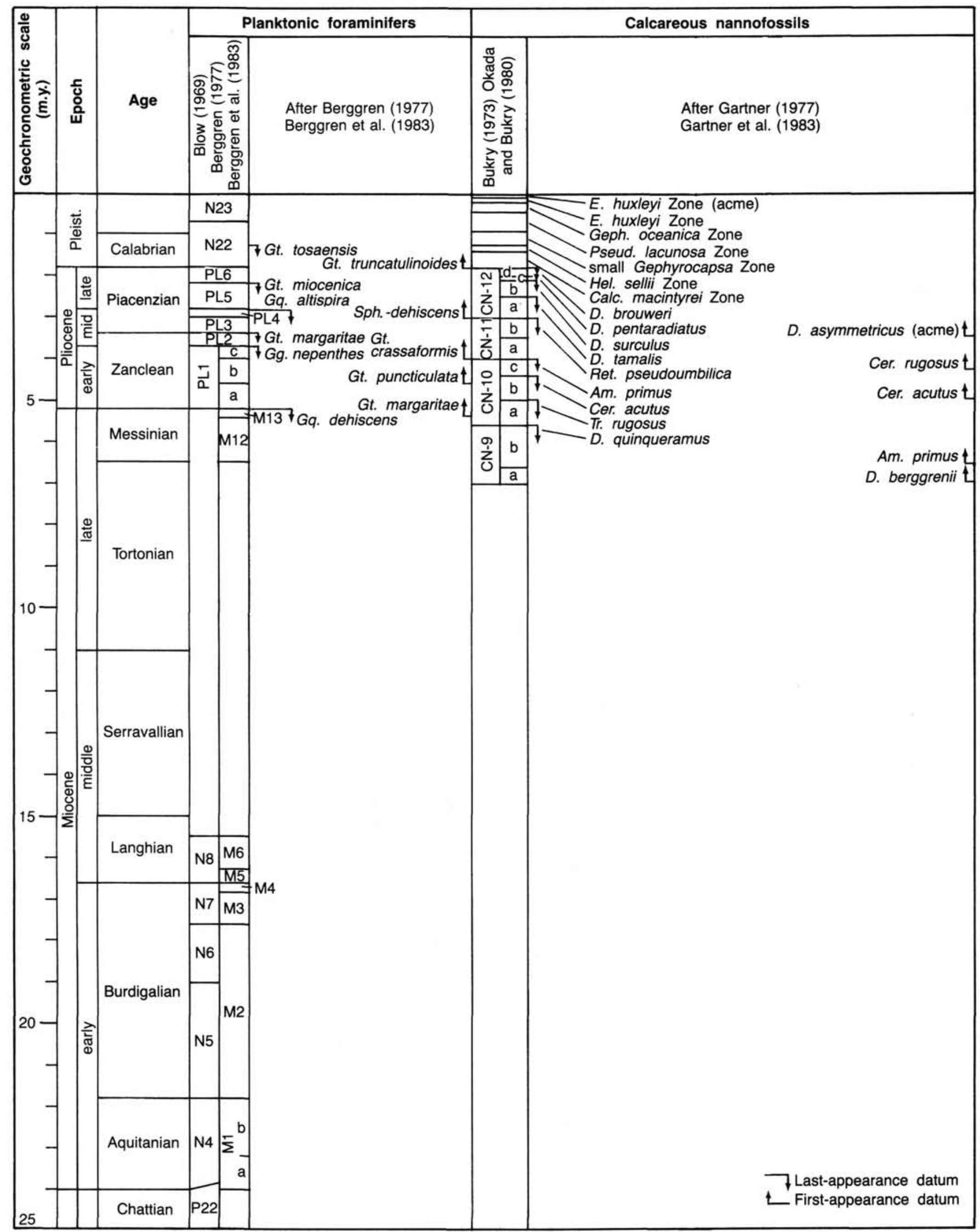

Figure 10. Neogene-Quaternary time scale and correlation of planktonic foraminiferal and calcareous nannofossil zonation schemes (time scale after Harland et al., 1982; Palmer et al., 1983; Berggren et al., 1983, in press). 


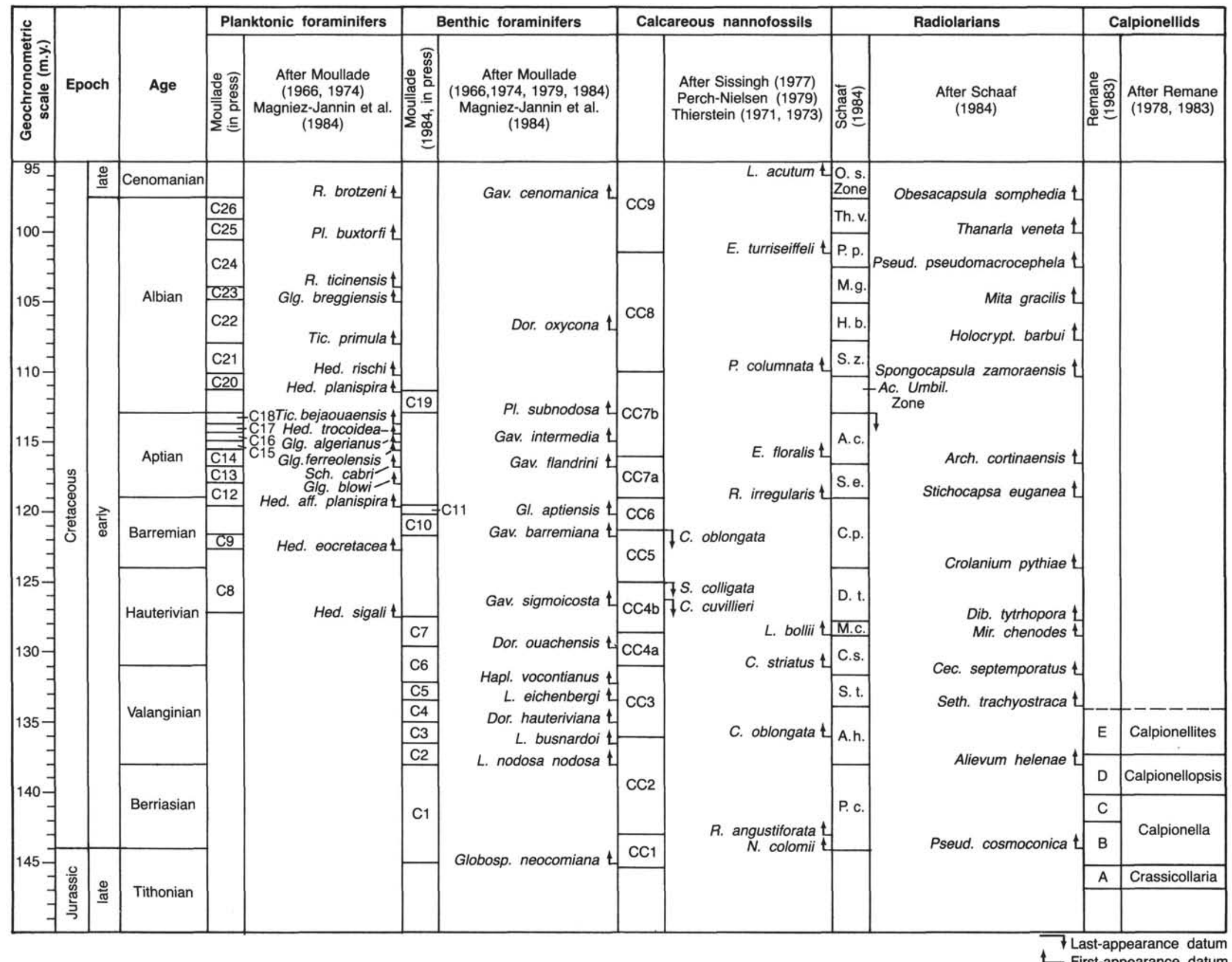


more convenient than SI units in discussing total and unit magnetization when the volume of the sample is measured in $\mathrm{cm}^{3}$ rather than in $\mathrm{m}^{3}$.

\section{Limitations of Shipboard Cryogenic Magnetometer}

The pass-through cryogenic magnetometer on board the JOIDES Resolution had neither been tested with rotary-cored material nor been taken to sea before Leg 103. This instrument can measure $1.5 \mathrm{~m}$ of whole-core material in increments as short as $0.25 \mathrm{~cm}$ on a conveyor system.

The cryogenic electronics can potentially measure fields greater than about $7 \times 10^{-8}$ total emu ( $0.001 \mathrm{phi}$ on an axis) and less than about $1.4 \times 10^{-1}$ total emu. For discrete samples, this range would be typical of the better cryogenic magnetometers on land, but some practical limitations result in a much narrower range for our use.

\section{Lower Limit of Effective Sensitivity}

The lower range of sensitivity is severely affected by cyclic background noise that correlates with the roll of the ship. In heavier seas, the "rolling" noise on the $\mathrm{X}$ and $\mathrm{Z}$ axes approached 0.04 phi, equivalent to about $3 \times 10^{-6}$ total emu. For a $10-\mathrm{cm}^{3}$ sample, such a noise level would produce a lower bound of $3 \times$ $10^{-7} \mathrm{emu} / \mathrm{cm}^{3}$. While the ship was on site, the maximum rolling noise was less than half of this value, still preventing the accurate measurement of nannofossil-marl samples. Therefore, the effective lower limit of measurement on the cryogenic magnetometer is about $1 \times 10^{-6}$ total emu, a decline by nearly an order of magnitude over the operating signal-to-noise ratio of stable land-based instruments. This is disappointing because it limits the use of the cryogenic magnetometer for discrete samples of many types of limestone. For whole-round portions of cores, the effective amount of material within the sense regions is nearly 40 times greater than single discrete samples; therefore, the rolling noise is insignificant (equivalent to less than $3 \times 10^{-9} \mathrm{emu} /$ $\mathrm{cm}^{3}$ ).

\section{Upper Limit of Measurement Range}

An upper limit of approximately $1.5 \times 10^{-1}$ total emu is introduced by the currently used electronics (when on "extended-" range setting). For a $10-\mathrm{cm}^{3}$ sample, this range enables the measurement of even the strongest basalts. Such an upper limit, however, becomes restrictive for measuring whole sections owing to the actual volume of material within the sense region of the superconducting quantum interference devices (SQUID). The sensor regions for each axis were measured during the Leg 102B transit, and the effective volume of material measured ranges from 300 to $450 \mathrm{~cm}^{3}$ for a typical core radius. A $400-\mathrm{cm}^{3}$ volume of sediment having a magnetization greater than $4 \times 10^{-4} \mathrm{emu} /$ $\mathrm{cm}^{3}$ would send the SQUID electronics off scale. When this happens, the electronics automatically reset; therefore, continued measurements during a pass-through are considerably distorted. This over-range effect was noted during measurement of nearly one-half of the whole-round sections of terrigenous-rich sediments and of all half-rounds of serpentinite basement.

\section{Effects of Rotary Drilling}

All whole-round rotary-drilled cores passing through the magnetometer displayed a strong normal-polarity magnetization, even upon alternating field demagnetization to 100 oersteds. To test the reliability of these results, especially considering that the paleontological-age determinations imply deposition during the reversed-polarity Matuyama Epoch (early Pleistocene), a series of discrete samples were taken as oriented cubes from the split sections. These discrete samples displayed a much lower magnetization per unit volume than did the whole-round measurements and a reversed polarity in several cores. For example, Core 103-
637A-14R displayed an average whole-round magnetization of 2 $\times 10^{-4} \mathrm{emu} / \mathrm{cm}^{3}$, but the four discrete samples taken from that section had a magnetization of only $1 \times 10^{-5} \mathrm{emu} / \mathrm{cm}^{3}$ at the same demagnetization step, an intensity only $5 \%$ of that expected from the whole-round analysis but more typical of clay-rich clastic sediments. The obvious interpretation is that the strong normal-polarity component of the whole-round core sections was absent in the original sediments and is instead present in the drilling slurry that fills the space between the intact sediment and the liner and occurs as an outer coating on the intact sediment pieces. There are at least three possible reasons for this: (1) Rotary drilling of terrigenous sediments may result in a concentration of heavier minerals, especially magnetite, in the slurry. (2) Rust particles from the pipes are often noted in the drilling slurry, and these have been suggested as a source of contamination (B. Clement, pers. comm., 1985; L. Tauxe, pers. comm., 1985). On the other hand, it is unclear how such large particles, if randomly oriented, could carry a magnetization oriented toward a consistent, stable normal-polarity inclination throughout the length of the core. (3) Upon dewatering during compression, the slurry acquires a pastelike texture, creating the same effect as shock remanent magnetization-a large part of the magnetite being oriented toward the ambient magnetic field and the net intensity per unit volume being much stronger than normal sediment of the same composition. Regardless of the combined causes, rotary drilling of sedimentary rocks, especially semiconsolidated terrigenous sediments, apparently results in an overwhelming alteration of the magnetization.

\section{Rust-Flake Contamination}

The outside surfaces of semi-indurated Neogene carbonate sediments were peppered with small brownish black rust flakes. The visible flakes are generally $1 \mathrm{~mm}$ in diameter, though some pieces exceed $3 \mathrm{~mm}$ in diameter. Whole-core measurements approached or exceeded the maximum reading range of the cryogenic magnetometer (Fig. 12A), implying a bulk magnetization of $4 \times 10^{-4} \mathrm{emu} / \mathrm{cm}^{3}$ or greater. By contrast, discrete samples taken from the interior of these cores have magnetizations of 5 $\times 10^{-6} \mathrm{emu} / \mathrm{cm}^{3}$ or weaker. These results imply that the wholecore analyses were not measuring the magnetization of the sediments but instead were measuring the density and orientation of the rust flakes.

A scraping from the outside of a block of nannofossil chalk having minimal visible rust-flake contamination registered a magnetization of $2 \times 10^{-4} \mathrm{emu} / \mathrm{cm}^{3}$, which is a value nearly two orders of magnitude stronger than that of the discrete chalk samples taken from the core interior (Fig. 12B). A sample of drilling slurry taken from between blocks of chalk and containing abundant sand-sized rust flakes had a magnetization of $5 \times 10^{-3}$ $\mathrm{emu} / \mathrm{cm}^{3}$, notably identical to the magnetic intensity of a typical oceanic basalt. A 3-mm-diameter rust flake imbedded in a 1$\mathrm{cm}^{3}$ block of chalk registered an off-scale reading, implying that the magnetization exceeded $1 \times 10^{-1} \mathrm{emu} / \mathrm{cm}^{3}$. All these tests show that rust-flake contamination during rotary coring renders the whole-round sections of any type of sediment useless for magnetic analysis. Use of a coated drill pipe, as planned beginning on Leg 104, will be necessary to eliminate this severe contamination.

\section{ORGANIC GEOCHEMISTRY}

Carbon, hydrogen, and nitrogen $(\mathrm{CHN})$ and Rock-Eval data were collected on board ship during Leg 103; organic-carbonisotope data were collected by $\mathrm{K}$. Dunham at the University of Michigan at Ann Arbor after the cruise. Procedures for collecting these data are described in the following sections. In addition, a number of potential organic contaminants on board the JOIDES Resolution were analyzed by gas chromatography aboard 

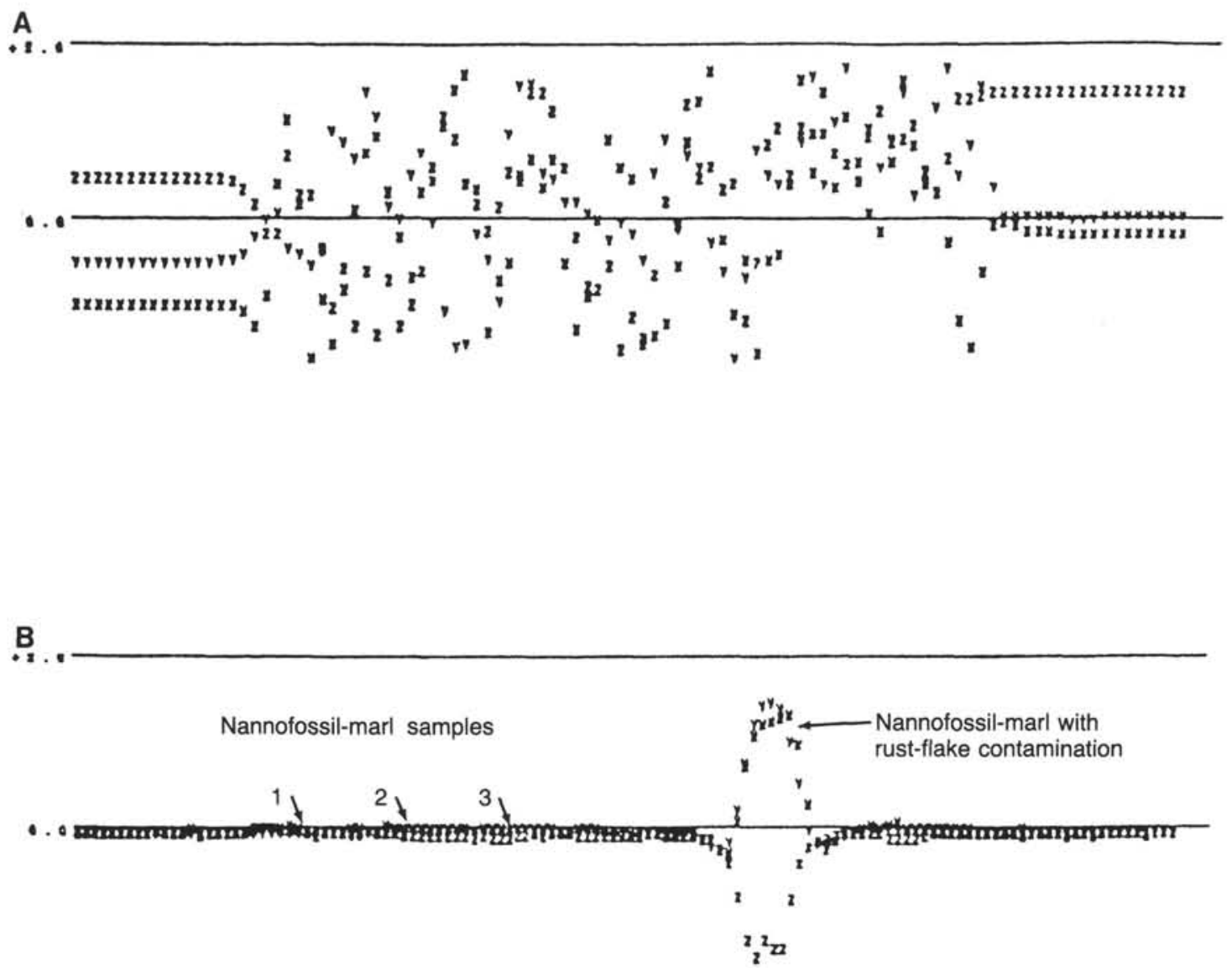

Figure 12. (A) Whole-core analysis of a section of Neogene nannofossil semi-indurated ooze (Section 103-638B-8R-2). At this extended maximum range for the sensors of the cryogenic magnetometer, the apparent magnetization was too strong to measure. Each sensor went off scale at least twice, indicating that the bulk magnetization exceeds $5 \times 10^{-4} \mathrm{emu} / \mathrm{cm}^{3}$. As a result, the data cannot be processed to determine magnetization directions, though the polarity obviously must be normal (negative $\mathrm{Z}$ values). Vertical-scale divisions are $1.5 \times 10^{-1}$ total emu (sample volume is approximately $400 \mathrm{~cm}^{3}$ ); horizontal scale represents $2.5 \mathrm{~m}$, of which $0.5 \mathrm{~m}$ at each end are background readings. (B) Magnetization of three discrete samples (6$\mathrm{cm}^{3}$ volume) of Neogene nannofossil semi-indurated marl taken from the interior of Section 103-638B-7R-1 compared with a scraping (1.5- $\mathrm{cm}^{3}$ volume) from the outside of a sediment piece from the same section. Even though the scraping showed only minimal visible rust-flake contamination, the intensity of magnetization $\left(1 \times 10^{-4} \mathrm{emu} / \mathrm{cm}^{3}\right)$ is approximately two orders of magnitude stronger than the internal sediment samples. The discrete samples have a magnetization of approximately $1 \times 10^{-6} \mathrm{emu} / \mathrm{cm}^{3}$, barely apparent above the background noise of the cryogenic magnetometer. Vertical-scale divisions are $1.5 \times 10^{-4}$ total emu; horizontal scale represents $2.5 \mathrm{~m}$, of which $0.5 \mathrm{~m}$ at each end are background readings.

ship. The results of these analyses are presented by Dunham (this volume).

\section{CHN Procedure}

Shipboard organic carbon analyses were made using a PerkinElmer $240 \mathrm{C}$ elemental analyzer. Selected sediment samples were treated with concentrated $\mathrm{HCl}$ to remove carbonates, washed with deionized water, and dried at $35^{\circ} \mathrm{C}$. A Cahn electrobalance was used to weigh a sediment sample of about $15 \mathrm{mg}$ for carbon, hydrogen, and nitrogen (CHN) analysis. Samples were combusted at $1000^{\circ} \mathrm{C}$ in the presence of oxygen, and the volumes of the evolved gases were determined as measures of the $\mathrm{C}, \mathrm{H}$, and $\mathrm{N}$ contents of organic matter. Concentrations were determined by the Perkin-Elmer 3600 Data Station and compared with those of known shipboard standards. The resultant hydrogen elemental data are untrustworthy because of variable amounts of clay minerals and their hydrates; hence, hydrogen values are not reported. Owing to technical problems, elemental nitrogen values were not reliable; therefore, they are also not reported. Organic carbon values were corrected for carbonate content and are reported on a dry-sediment weight basis.

\section{Rock-Eval Procedure}

The source character and maturity of organic matter in selected sediment samples were determined with the shipboard Delsi Nermag Rock-Eval II pyrolysis instrument, which uses the process described by Espitalie et al. (1977). About $100 \mathrm{mg}$ of coarsely ground, dry sample was heated from $250^{\circ} \mathrm{C}$ to $550^{\circ} \mathrm{C}$ at a rate of $25^{\circ} \mathrm{C} / \mathrm{min}$. Gases released during this heating were carried off in a helium stream, which was split into two parts. One part was directed through a flame ionization detector to monitor hydrocarbons. The other passed through a $\mathrm{CO}_{2}$ trap from which the total amount of evolved $\mathrm{CO}_{2}$ was released at the end of the heating program to be measured by a thermal-conductivity detector.

This pyrolysis procedure yields four parameters characteristic of the organic matter in a sample:

1. Area of peak $S_{1}$, which corresponds to the quantity of hydrocarbons in the sample

2. Area of peak $\mathrm{S}_{2}$, which corresponds to the quantity of hydrocarbons released by pyrolysis of kerogen up to $550^{\circ} \mathrm{C}$, or the "hydrocarbon potential" 
3. Temperature, $T_{\max }$, of the top of peak $\mathrm{S}_{2}$, which is related to the maturity of the organic matter

4. Area of peak $\mathrm{S}_{3}$, which corresponds to the $\mathrm{CO}_{2}$ released from pyrolysis of kerogen

From $\mathrm{S}_{2}, \mathrm{~S}_{3}$, and the organic carbon concentration, the hydrogen index (HI) and oxygen index (OI) were calculated and used to determine kerogen source character and maturity.

\section{Organic Carbon Isotope Procedure}

Samples for isotope determination were prepared using the sealed-tube method. Stable carbon isotope ratios of the organic carbon content were determined on carbonate-free samples, using a VG Micromass 602 mass spectrometer calibrated with NBS-20 (carbonate) and NBS-22 (petroleum) standards. Data were corrected to ${ }^{17} \mathrm{O}$ and are presented in the site chapters (this volume) relative to the PDB standard.

\section{INORGANIC GEOCHEMISTRY}

\section{Interstitial Waters}

Interstitial waters were routinely analyzed for $\mathrm{pH}$, alkalinity, salinity, chlorinity, calcium, and magnesium during Leg 103. The method of obtaining interstitial waters from the sediment, using a stainless-steel press, was described in detail by Manheim and Sayles (1974). IAPSO standard seawater is the primary standard for water analyses aboard ship.

Alkalinity and $\mathrm{pH}$ were determined using a Metrohm titrator with a Brinkmann combination $\mathrm{pH}$ electrode. The $\mathrm{pH}$ value of the sample was calibrated with $4.01,6.86$, and 7.41 buffer standards; readings were taken in millivolts and then converted to $\mathrm{pH}$. The $\mathrm{pH}$ measurements were made immediately before the alkalinity measurements. The 5- to $10-\mathrm{mL}$ interstitial-water sample, after being tested for $\mathrm{pH}$, was titrated with $0.1 \mathrm{~N} \mathrm{HCl}$ as a potentiometric titration (Gieskes, 1973).

Salinity was determined using a Goldberg optical refractometer, which measures the amount of total dissolved solids. Sayles et al. (1970) found that this "salinity" agreed well with their measured ion sums.

Chlorinity was determined by titrating a $0.1-\mathrm{mL}$ sample (diluted with $5 \mathrm{~mL}$ of deionized water) with silver nitrate. The Mohr titration uses potassium chromate as an indicator.

The amount of calcium present was determined by complexometric titration of a $0.5-\mathrm{mL}$ sample with EGTA, using GHA as an indicator. To aid determination of the endpoint, the calciumGHA complex was extracted into a layer of butanol (Gieskes, 1973). No correction was made for strontium, which is also included in the result.

The concentration of magnesium was determined by EDTA titration for total alkaline earths (Gieskes, 1974). Subsequent subtraction of the calcium value (also includes strontium) yielded the magnesium concentration in the interstitial-water sample.

\section{Calcium Carbonate}

Percentage carbonate was determined on board ship by the carbonate-bomb technique (Müller and Gastner, 1971). The sample was freeze-dried, ground to a powder, and then combined with $\mathrm{HCl}$ in a closed cylinder. Any resulting $\mathrm{CO}_{2}$ pressure is proportional to the percentage $\mathrm{CO}_{3}$ of the dried-sediment weight of the sample. Error can be as low as $1 \%$ for sediments high in $\mathrm{CO}_{3}$; overall accuracy is typically $2 \%$ to $5 \%$.

\section{PHYSICAL PROPERTIES}

A thorough discussion of physical properties with respect to equipment, methods, errors, correction factors, and problems related to coring disturbance was presented by Boyce $(1973 ; 1976)$. Only a brief review of methods employed on Leg 103 is given here.

\section{Gamma Ray Attenuation Porosity Evaluator}

The gamma ray attenuation porosity evaluator (GRAPE), described in detail by Boyce (1976), was used to continuously measure the bulk density of material in core sections more than 50 $\mathrm{cm}$ long. Where indurated rock samples did not completely fill the core liner, the diameter of the rock pieces was individually measured with a caliper and the data entered in a specially designated column on the shipboard visual core-description forms alongside the graphic representation of the measured piece.

Two-minute GRAPE measurements were made on discrete samples, using the same samples for which compressional seismic velocity and index properties were measured (see following text). Metasedimentary and altered igneous rocks were recovered from Holes 639E and 639F in amounts too small to warrant destruction during carbonate-bomb analysis (Müller and Gastner, 1971); 2-min GRAPE bulk-density measurements on thin-section billets are the only bulk-density data available for these samples. Two-minute GRAPE and gravimetric bulk-density data are compared in the following text.

\section{Thermal Conductivity}

Thermal-conductivity measurements were made on undisturbed sediments from cores that recovered material soft enough to yield to needle-probe insertion. Cores were allowed to warm to stable temperature for $4 \mathrm{hr}$ before measurement. Temperature drift was generally less than $0.05^{\circ} \mathrm{C} / \mathrm{min}$ at the time of thermal-conductivity measurement. The Thermcon- 82 apparatus supplied by Woods Hole Oceanographic Institution for thermal-conductivity measurement maintains a reference voltage of 1.48 in ideal conditions. This voltage slowly increased to 1.53 volts during Leg 103. To evaluate the consequences of using a default reference voltage of 1.48 , we ran results of measurements through the data-processing program, using the observed reference voltage and the default value; the difference in calculated thermal conductivity is less than $1.5 \%$. Data records for Holes $641 \mathrm{~A}$ and $641 \mathrm{C}$ include observed reference voltage.

\section{Vane Shear}

A complete discussion of the vane-shear apparatus and shearstrength measurement appears in Boyce (1973). Measurements of vane-shear strength were routinely made on sediments having shear strengths less than about 70 kiloPascals (i.e., until the sediment was of sufficient cohesive strength to form drilling "biscuits" or to destroy the vane-shear device).

\section{Velocity}

Compressional sound velocity at $400 \mathrm{kHz}$ was measured through sediments, sedimentary rocks, and igneous rocks with a Hamilton Frame velocimeter, using a Tektronix 5110 oscilloscope and Tektronix TM5006 counter/timer. Sound-velocity correction factors were calculated for each hole on Leg 103 as described by Boyce (1976).

\section{Index Properties}

Index properties (bulk and grain density, porosity, and water content) were routinely measured gravimetrically on the same samples for which seismic velocity was measured. Samples were placed in preweighed and numbered aluminum beakers and weighed in the beakers on a triple-beam balance. The volume of sample and container was then measured on the shipboard PentaPycnometer, which first purges the sample chamber of air and then floods the sample chamber with helium gas at a pressure of $19 \mathrm{lb} /$ in. $^{2}$ The volume of sample and container was calculated from the difference between the volume of helium in the empty sample chamber and that in the chamber with sample. Samples were then freeze-dried, weighed, and their dry volume measured. 
Index properties were then calculated by a computer program in which sample container identification and volume had been previously entered.

Bulk density was also routinely measured on the same sample by 2 -min GRAPE analysis (see previous text). In calculating true bulk density of a sample, rather than using an assumed grain density as described by Boyce (1976), we used the grain density derived for that particular sample by gravimetric technique. The 2-min GRAPE bulk-density values are systematically slightly lower than the gravimetrically derived bulk-density values; the difference is generally less than $5 \%$, except where gravimetric measurement was performed on small samples, as discussed as follows.

Volume-measurement error is less than $5 \%$ except for small samples $\left(<3 \mathrm{~cm}^{3}\right)$, for which volume measurement erred conservatively to yield unrealistically large bulk-density values. This occurred during Leg 103 at Sites 637 and 639, where only small samples of serpentinite, dolomite, and the variety of rocks recovered from Holes $639 \mathrm{E}$ and $639 \mathrm{~F}$ were available for gravimetric analysis. Gravimetrically derived bulk density of these rocks is 7\%-15\% in excess of expected bulk densities and of bulk density obtained by 2 -min GRAPE analysis.

After measurement of sample dry weight and dry volume, the carbonate content of the samples was measured using the carbonate-bomb method (Müller and Gastner, 1971).

\section{DOWNHOLE LOGGING}

Downhole logging is perhaps best known for its wide use in petroleum exploration for correlation and stratigraphic studies and for the evaluation of formation fluids and lithology. At ODP drill sites, logging is important for determining in-situ sonic velocities to correlate accurately seismic reflectors with lithology, for comparing shipboard determinations of physical properties with those measured in situ, and for determining the lithology of poorly recovered intervals.

The general principles and operation of the downhole-logging tools used during Leg 103 are discussed here; preliminary interpretation of the Leg 103 downhole logs is given in each site chapter (this volume). The information presented in this section is modified from the first edition of the wireline-logging manual prepared by the Borehole Research Group of the Lamont-Doherty Geological Observatory (L-DGO) (1985), the wireline-logging contractor for ODP. Additional information about ODP logging is available from Roger N. Anderson at L-DGO.

\section{Long-Spacing Sonic Log}

The long-spacing sonic log (LSS) provides an improved measurement of the sonic transit time. The sonde measures the time required for a compressional sound wave to travel through $1 \mathrm{ft}$ of formation. Two transmitters spaced $2 \mathrm{ft}$ apart are located $8 \mathrm{ft}$ below two receivers, which are also $2 \mathrm{ft}$ apart. Hole-size compensation is obtained by recording the first interval traveltime reading and averaging it with a second reading measured after the sonde has been pulled up a fixed distance along the borehole. Owing to its longer spacing (10-12 in.), the sonde has a deeper investigation depth, so the altered zone near the borehole does not affect the measurement. ft.

The interval traveltime (DT and/or DTL) is recorded in $\mu \mathrm{s} /$

The LSS log can be used to evaluate porosity in clean and consolidated sandstone and in dispersed shale and also to provide good porosity data in carbonate formations having intergranular porosity. In vuggy or fractured formations, the response depends mostly on primary porosity; the sonde measures the first arrival of the sonic wave taking the quickest path (i.e., the lowest porosity path). Combined with data from the density- neutron tool, which measures total porosity, the secondary porosity can be calculated. In unconsolidated and uncompacted sands where interval traveltime values are more influenced by formation fluids, the porosity can be calculated by applying an appropriate compaction factor.

LSS tools are also used to provide shear-wave analysis and more accurate data in enlarged holes and in areas where formations have been damaged by drilling operations. Waveforms and variable-density displays are used for fracture detection. The integrated traveltime provides formation velocity data useful in seismic interpretation.

\section{Dual Induction Log}

The dual induction log (DIL) tool provides a spontaneous potential (SP) curve and three resistivity measurements at different investigation depths: ILD (virgin zone), ILM (invaded zone), and SFLU (flushed zone). The DIL sonde includes a system of several transmitter and receiver coils. High-frequency alternating currents sent through the transmitter coils create magnetic fields that induce secondary currents in the formation. These ground-loop currents create new magnetic fields, inducing signals to the receiver coils, which are proportional to the conductivity of the formation. The DIL sonde also incorporates a focused device, the SFL, for readings in the flushed zone.

ILD, ILM, and SFLU curves are displayed in ohm-m. Because the DIL tool measures conductivity, errors are negligible at low-resistivity values but can increase considerably $(>20 \%)$ where resistivity is greater than $100 \mathrm{ohm}-\mathrm{m}$.

The DIL provides a good determination of invasion profiles and hence an accurate evaluation of the formation resistivity in instances of deep invasion.

\section{Standard Gamma-Ray Log}

The gamma-ray log (GR) measures the natural radioactivity of the formation. Most gamma rays are emitted by the radioactive isotope of $\mathrm{K}^{40}$ and by radioactive elements of the $\mathrm{U}$ and $\mathrm{Th}$ series. Passing through the material, gamma rays are scattered by collisions with the atoms of the formation, losing energy until they are absorbed through the photoelectric effect. The absorption is proportional to the bulk density of the formation. Gamma-ray radiation originating in the formation near the borehole is measured by a scintillation detector mounted on the sonde. The average radial investigation depth in sedimentary formations is about $1 \mathrm{ft}$.

The GR curve is displayed in API units, typically combined with a caliper. API unit calibration has replaced the old scale of micrograms of radium-equivalent per ton of formation. The radioactivities observed in sedimentary formations range from a few API units (salt or anhydrite) to 200 or more in shales.

The GR curve provides a qualitative evaluation of clay or shale content because radioactive elements tend to concentrate in shales and clays. Clean formations typically show low radioactivities; however, some rock matrices may have radioactivities ranging from moderate to high values, owing to the presence of volcanic ash, granite wash, or other radioactive materials. The GR log can also be used for the detection of coal beds.

\section{Lithodensity Log}

The lithodensity log (LDT) utilizes a radioactive source, mounted on a pad applied to the hole wall by a centering arm, which emits gamma rays into the formation. These gamma rays are scattered by collisions with the atoms of the formation, losing energy until they are absorbed through the photoelectric effect. The number of scattered gamma rays reaching the two detectors (short and long spacing) at fixed distances from the source is related to the electron density of the formation, which in turn de- 
pends on the true bulk density. The photoelectric-effect measurement is related to the formation lithology, and the bulk density to the porosity.

The bulk-density curve (RHOB) is displayed in $\mathrm{gm} / \mathrm{cm}^{3}$. When run in combination with the compensated neutron log (see following section), both porosity curves are recorded on the same track, permitting a quick visual evaluation of lithology and porosity. The photoelectric-effect curve (PEF) is displayed in barns/ electron.

Porosity values can be derived directly from the density curve if the value of the formation grain density is known. However, a more accurate porosity determination is achieved using additional porosity curves (compensated neutron or sonic). Simple sediment types can be determined directly from the PEF curve. In complex sediments (mixtures of as much as three minerals), the use of PEF and of the matrix-density values provides an accurate determination of the different components.

\section{Compensated Neutron Log}

The compensated neutron $\log (\mathrm{CNT})$ utilizes a radioactive source mounted on a sonde that emits fast neutrons, which are scattered and slowed by collisions with the nuclei in the formation. Whenever they reach the "thermal" energy level, they are captured by the nuclei of atoms, such as hydrogen, chlorine, and silicon; gamma rays of capture are then emitted. Two detectors count both epithermal (intermediate) and thermal (slow) neutrons. The ratio of counting rates from the detectors is processed by the surface equipment to provide a linearly scaled record of neutron porosity. This compensated measurement greatly reduces the effect of borehole conditions.

The radial investigation depth has been largely improved owing to longer source-detector spacing. However, this depth primarily depends on the porosity; in higher porosity formations, it decreases because neutrons are slowed and captured closer to the borehole.

The CNT is recorded in linear porosity units for a particular lithology (limestone, sandstone, dolomite). When run in combination with a density log, both curves are recorded on the same track, providing an initial qualitative evaluation of lithology and porosity.

Values of apparent porosity may be directly derived from the neutron log. A more accurate determination of porosity, lithology, and clay content, however, involves additional information from density and/or sonic logs.

\section{Natural Gamma-Ray Spectrometry Log}

The natural gamma-ray spectrometry log (NGT) can measure the three different components (potassium [K], thorium [Th], and uranium [U]) of the detected gamma-ray spectrum, differentiating between gamma rays of different energies. The sonde employs a sodium iodide scintillation detector contained in a pressure housing, which is pressed against the hole wall by a bowspring during logging. A downhole electronic amplifier transmits pulses through the logging cable to the surface panels, including a multichannel analyzer, which displays the entire spectrum and selects pulses within preselected energy windows. At the highenergy end of the gamma-ray spectrum, Th is recorded directly; $\mathrm{U}$ and $\mathrm{K}$ are determined with a stripping technique.

A standard presentation of the NGT data displays five curves: SGR (total GR) and CGR (computer GR minus the U component) scaled in API units, THOR and URAN scaled in parts per million, and POTA scaled as a proportion.

The NGT allows a detailed mineralogical identification in the formation and, consequently, an accurate evaluation of the following sediment types:
1. Sandstone: Th is indicative of heavy minerals, Th and $\mathrm{K}$ of clay content.

2. Carbonates: $\mathrm{U}$ is due to the presence of organic matter and sulfates.

3. Shale: $\mathbf{K}$ content is related to the type of clay and mica content; Th depends on the amount of detrital material.

4. Igneous rocks: The relative proportions of the three radioactive families and particularly the ratios Th:K and Th:U are indicative of the rock type.

\section{Multichannel Sonic Logging}

The multichannel sonic log (MCS) device is a multireceiver single-source sonic-logging tool, which records 12 sonic waveforms at each source depth. The MCS tool is manufactured by SIMPLEC and is run on the ODP drill ship by the L-DGO logger.

On the MCS tool, the source is above the receiver string, separated by a variable-length spacer assembly. The receivers are spaced $15 \mathrm{~cm}$ apart, resulting in a $1.65-\mathrm{m}$ receiver array. The MCS geometry is therefore similar to that of a surface-refraction survey. During the logging run, the MCS tool is centered in the borehole by bowspring centralizers. The energy that arrives at the receiver array travels as a compressional pulse in the borehole fluid. At the borehole wall, this energy is refracted back into the borehole fluid and recorded at the receivers. Additional guided modes are typically produced in the borehole environment, and their propagation is controlled by the properties of both the formation and the fluid-filled borehole.

The Masscomp computer controls the tool during logging, allowing the operator to select the depth increment between recorded suites as well as the number of receivers to be used. The data are digitized by the Masscomp and recorded on magnetic tape during the logging run. The MCS log is obtained while logging uphole at a rate that depends on the depth increment and number of receivers selected. For a $0.3-\mathrm{m}$ depth increment and 12 receivers per source depth, typical logging rates are currently about $3 \mathrm{~m} / \mathrm{min}$.

The MCS waveforms can be analyzed to yield compressional, shear, and Stoneley velocities across the receiver spread using a modified Semblance calculation. In addition, variations in frequency content and amplitude of the individual modes can be determined. Although the standard Schlumberger sonic logs can provide accurate compressional velocities, the additional information provided by the MCS tool allows the complete characterization of the elastic properties of the formation. The final output can be displayed either in log format or in full-waveform format on the Versatec plotter.

\section{OBTAINING SAMPLES}

Potential investigators wishing to obtain samples should refer to the ODP-NSF Sample Distribution Policy. Sample-request forms may be obtained from the Curator, Ocean Drilling Program, 1000 Discovery Drive, College Station, Texas 77840. Requests must be as specific as possible; include site, hole, core, section, interval within a section, and volume of sample required.

\section{REFERENCES}

Baumgartner, P. O., 1984. A Middle Jurassic-Early Cretaceous lowlatitude radiolarian zonation based on unitary associations and age of Tethyan radiolarites. Eclogae Geol. Helv., 77(3): 729-837.

Berggren, W. A., 1977. Late Neogene planktonic foraminiferal biostratigraphy of the Rio Grande Rise (South Atlantic). Marine Micropaleont., 2: 265-313.

Berggren, W. A., 1983. Correlation of Atlantic, Mediterranean and Indo-Pacific Neogene stratigraphies: geochronology and chronostratigraphy. IGCP Project 114: International Workshop on Pacific Ne- 
ogene Biostratigraphy (Osaka and Kobe, Japan), November 24-29, 1981.

Berggren, W. A., Aubry, M. P., and Hamilton, N., 1983. Neogene magnetobiostratigraphy of Deep Sea Drilling Project Site 516 (Rio Grande Rise, South Atlantic). In Barker, P. F., Carlson, R. L., Johnson, D. A., et al., Init. Repts. DSDP, 72: Washington (U.S. Govt. Printing Office), 675-713.

Berggren, W. A., Kent, D. V., and Van Couvering, J. A., in press. Neogene geochronology and chronostratigraphy. In Snelling, N. J. (Ed.), Geochronology and the Geological Record. Geol. Soc. of London Spec. Pap.

Blow, W. H., 1969. Late Middle Eocene to Recent planktonic foraminiferal biostratigraphy. In Broenniman, P., and Renz, H. H., (Eds.), Proc., First Int. Conf. Plankt. Microfossils: Leiden (E. J. Brill), 1: 199-422.

Boyce, R. E., 1973. Appendix I. Physical property methods. In Edgar, N. T., Saunders, J. B., et al., Init. Repts. DSDP, 15: Washington (U.S. Govt. Printing Office), 1115-1128.

Boyce, R. E., 1976. Appendix I. Definitions and laboratory techniques of compressional sound velocity parameters and wet-water content, wet-bulk density, and porosity parameters by gravimetric and gamma ray attenuation techniques. In Schlanger, S. O., Jackson, E. D., et al., Init. Repts. DSDP, 33: Washington (U. S. Govt. Printing Office), 931-958.

Bukry, D., 1973. Low-latitude coccolith biostratigraphic zonation. In Edgar, N. T., Saunders, J. B., et al., Init. Repts. DSDP, 15: Washington (U.S. Govt. Printing Office), 685-703.

Bukry, D., 1975. Coccolith and silicoflagellate stratigraphy, northwestern Pacific Ocean, Deep Sea Drilling Project Leg 32. In Larson, R. L., Moberly, R., et al., Init. Repts DSDP, 32: Washington (U.S. Govt. Printing Office), 677-701.

Busnardo, R., Thieuloy, J. P., and Moullade, M. (Eds.), 1979. Hypostratotype mésogéen de l'étage Valanginien. Les Stratotypes français, Publ. C.N.R.S., 6:110-126.

Dunham, R. J., 1962. Classification of carbonate rocks according to depositional texture. In Ham, W. E. (Ed.), Classification of Carbonate Rocks. Am. Assoc. Petrol. Geol. Mem. 1: 108-121.

Embry, A. F., and Klovan, J. E., 1971. A Late Devonian reef tract on northeastern Banks Island, Northwest Territories. Can. Petrol. Geol. Bull., 19: 730-781.

Espitalie, J., Madec, M., and Tissot, B., 1977. Source rock characterization method for petroleum exploration. Offshore Technology Conf. Proc., 399-404.

Gartner, S., 1977. Calcareous nannofossil biostratigraphy and revised zonation of the Pleistocene. Mar. Micropaleontol., 2:1-25.

Gartner, S., Chen, M. P., and Stanton, R. J., 1983. Late Neogene nannofossil biostratigraphy and paleoceanography of the northeastern Gulf of Mexico and adjacent areas. Mar. Micropaleontol., 8:17-50.

Gealy, E. L., Winterer, E. L., and Moberly, R. M., Jr., 1971. Methods, conventions, and general observations. In Winterer, E. L., Riedel, W. R., et al., Init. Repts. DSDP, 7, Pt. 1: Washington (U.S. Govt. Printing Office), 9-26.

Gieskes, J. M., 1973. Interstitial water studies, Leg 15. Alkalinity, pH, $\mathrm{Mg}, \mathrm{Ca}, \mathrm{Si}, \mathrm{PO}_{4}$ and $\mathrm{NH}_{4}$. In Heezen, B. C., MacGregor, I. G., et al., Init. Repts. DSDP, 15: Washington (U.S. Govt. Printing Office), 813-829.

Gieskes, J. M., 1974. Interstitial water studies, Leg 25. In Simpson, E. S. W., Schlich, R., et al., Init. Repts. DSDP, 25: Washington (U.S. Govt. Printing Office), 361-394.

Harland, W. B., Cox, A. V., Llewellyn, P. G., Pickton, C. A. G., Smith, A. G., and Walters, R., 1982. A Geologic Time Scale: Cambridge (Cambridge Univ. Press), 1-131.

Hay, W. W., 1970. Calcareous nannofossils from cores recovered on Leg 4. In Bader, R. G., Gerard, R. D., et al., Init. Repts. DSDP, 4: Washington (U.S. Govt. Printing Office), 455-501.

Kennett, J. P., and Srinivasan, S., 1983. Neogene Planktonic Foraminifera: A Phylogenetic Atlas. Stroudsburg, PA (Hutchison-Ross).

Lamont-Doherty Geological Observatory, The Borehole Research Group, 1985. Wireline Logging Manual: Palisades, N.Y.

Magniez-Jannin, F., Moullade, M., and Tronchetti, G., 1984. Crétacé inférieur: repartition des principaux foraminifères planctoniques et benthiques de bassin. In Debrand-Passard, S. (Ed.), Synthèse géologique du Sud-Est de la France. Mem. B.R.G.M., 125:297-299.
Manheim, F. T., and Sayles, F. L., 1974. Composition and origin of interstitial waters of marine sediments based on deep sea drill cores. In Goldberg, E. D., (Ed.), The Sea, 5: New York (Wiley-Interscience), 527-568.

Manivit, H., Perch-Nielsen, K., Prins, B., and Verbeek, J. W., 1977. Mid-Cretaceous calcareous nannofossil biostratigraphy. Koninkl. Nederlandse Akad. Wetensch. Proc., Ser. B, 80: 169-181.

Matthews, D. J., 1939. Tables of Velocity of Sound in Pore Water and in Seawater: London (Admiralty, Hydrographic Department).

Moullade, M., 1966. Étude stratigraphique et micropaleontologique du Crétacé inférieur de la "fosse vocontienne." Doc. Lab. Geol. Fac. Sci., Lyon, 15:1-369.

Moullade, M., 1974. Zones de Foraminifères du Crétacé inférieur mesogéen. Acad. Sci., Paris, C. R. ser. D, 278:1813-1816.

Moullade, M., 1979. Les Foraminifères du Valanginien hypostratotypique. In Busnardo, R., Thieuloy, J. P., Moullade, M. (Eds.). Hypostratotype mesogéen de l'étage Valanginien. Les Stratotypes français, Publ. C.N.R.S., 6:110-126.

Moullade, M., 1983. Upper Neogene and Quaternary planktonic foraminifera from the Blake Outer Ridge and Blake Bahama Basin (Western North Atlantic). In Sheridan, R. E., Gradstein, F. M., et al., Init. Repts. DSDP, 76: Washington (U.S. Govt. Printing Office), 511-535.

Moullade, M., 1984. Intérèt des petits foraminifères benthique profonds pour le biostratigraphie et l'analyse des paléoenvironnements océaniques mésozoiques. IId. Int. Symp. Benth. Foraminifera, "Benthos '83," Pau, 1983, 429-464.

Moullade, M., in press. Distribution of Neogene and Quaternary planktonic foraminifers from the upper continental rise of the New Jersey margin (western North Atlantic) DSDP Site 604: Biostratigraphical analysis, sedimentary and paleoceanographic implications. Init. Repts. $D S D P$, 93: Washington (U.S. Govt. Printing Office).

Müller, G., and Gastner, M., 1971. The "Karbonat-Bombe," a simple device for determination of the carbonate content in sediments, soils and other materials. Neues. Jahrb. Mineral. Mh., 10:466-469.

Ogg, J. G., 1981. Magnetostratigraphy of Upper Jurassic and lowest Cretaceous sediments, Deep Sea Drilling Project Site 534, western North Atlantic. In Sheridan, R. E., Gradstein, F. M., et al., Init. Repts. DSDP, 76: Washington, (U.S. Govt. Printing Office), 685697.

Ogg, J. G., in press. Early Cretaceous magnetostratigraphy, DSDP Sites 534 and 603, western North Atlantic. In Van Hinte, J., Wise, S., et al., Init. Repts. DSDP, 93: Washington, (U.S. Govt. Printing Office).

Okada, H., and Bukry, D., 1980. Supplementary modification and introduction of Code numbers to the low-latitude coccolith biostratigraphic zonation (Bukry, 1973:1975). Mar. Micropaleontol., 5:321325.

Palmer, A. R., 1983. The Decade of North American Geology time scale. Geology, 11:503-504.

Perch-Nielsen, K., 1979. Calcareous nannofossils from the Cretaceous between the North Sea and the Mediterranean. In Wiedmann, J. (Ed.), Aspekte der Kreide Europas. Int. Union Geol. Sci. Ser. A, 6 Stuttgart (Schweizerbart): 223-272.

Remane, J., 1978. Calpionellids. In Haq, B. U., and Boersma, A. (Eds.), Introduction to Marine Micropaleontology: New York (Elsevier), 161170.

Remane, J., 1983. Calpionellids and the Jurassic/Cretaceous boundary at Deep Sea Drilling Project Site 534, western North Atlantic Ocean. In Sheridan, R.E., Gradstein, F.M., et al., Init. Repts. DSDP, 76: Washington (U.S. Govt. Printing Office), 561-566.

Roth, P. H., 1983. Jurassic and Lower Cretaceous calcareous nannofossils in the western North Atlantic (Site 534). Biostratigaphy, preservation, and some observations on biogeography and paleoceanography. In Sheridan, R. E., Gradstein, E. M., et al., Init. Repts. DSDP., 76: Washington (U.S. Govt. Printing Office), 587-621.

Roth, P. H., Medd, A. W., and Watkins, D. K., 1983. Jurassic calcareous nannofossil zonation, an overview with new evidence from Deep Sea Drilling Project Site 534. In Sheridan, R. E., Gradstein, E. M., et al., Init. Repts. DSDP, 76: Washington (U.S. Govt. Printing Office), 573-579.

Sayles, F. L., Manheim, F. T., and Chan, K. M., 1970. Interstitial water studies on small core samples, Leg 4. In Bader, R. G., Gerard, R. D., et al., Init. Repts. DSDP, 4: Washington (U.S. Govt. Printing Office), 401-414. 
Schaaf, A., 1981. Late Early Cretaceous Radiolaria from Deep Sea Drilling Project Leg 62. In Thiede, J., Vallier, T. L., et al., Init. Repts. $D S D P, 62$ : Washington (U.S. Govt. Printing Office), 419-470.

Schaaf, A., 1984. Les radiolaires du Crétacé inférieur et moyen: biologie et systématique. Sciences géologiques, Mémoire 75.

Sissingh, W., 1977. Biostratigraphy of Cretaceous calcareous nannoplankton. Geol. Mijnbouw, 56:37-65.

Steiner, M. B., 1977. Magnetization of Jurassic red deep-sea sediments in the Atlantic (DSDP Site 105). Earth Planet. Sci. Lett., 35:205-214.

Supko, P., Ross, D. A., and Neprochnov, Y. P., 1978. Introduction and explanatory notes, Leg 42B, Deep Sea Drilling Project. In Ross, D. A., Neprochnov, Y. P., et al., Init. Repts. DSDP, 42, Pt.2: Washington (U.S. Govt. Printing Office), 3-15.
Thierstein, H. R., 1971. Tentative Lower Cretaceous nannoplankton zonation. Eclogae Geol. Helv., 64:459-488.

Thierstein, H. R., 1973. Lower Cretaceous calcareous nannoplankton biostratigraphy. Abh. Geol. Bundesanstalt (Wien), 29-52.

Wentworth, C. K., 1922. A scale of grade and class terms of clastic sediments. J. Geol., 30:377-390.

Wentworth, C. K., and Williams, H., 1932. The classification and terminology of the pyroclastic rocks. Rept. Comm. Sedimentation, Bull. Natl. Res. Counc. (U.S.), 80:10-53.

Wilson, J. L., 1975. Carbonate Facies in Geologic History. New York (Springer-Verlag). 